University of Miami Law School

University of Miami School of Law Institutional Repository

2010

The Case against Shareholder Empowerment

William Wilson Bratton

Follow this and additional works at: https://repository.law.miami.edu/fac_articles

Part of the Law Commons 


\title{
ARTICLE
}

\section{THE CASE AGAINST SHAREHOLDER EMPOWERMENT}

\author{
WILLIAM W. BRATTON ${ }^{\dagger} \&$ MICHAEL L. WACHTER ${ }^{\dagger}$
}

Many look toward enactment of the law-reform agenda held out by proponents of shareholder empowerment as a part of the regulatory response to the current financial crisis. This Article argues that the financial crisis exposes major weaknesses in the shareholder empowerment case. Our claim is that shareholder empowerment delivers management a simple and emphatic marching order: manage to maximize the market price of the stock. This is exactly what the managers of a critical set of financial firms did in recent years. They managed to a market that focused on increasing observable earmings, and, as it turned out, they failed to factor in concomitant increases in risk that went largely unobserved. The fact that management bears primary responsibility for the disastrous results does not suffice to effect a policy connection between increased shareholder power and sound regulatory reform. A policy connection instead turns on a counterfactual question: whether increased shareholder power would have imported more effective risk management in advance of the crisis. We conclude that no plausible grounds exist for making such a case. In the years preceding the financial crisis, shareholders validated the strategies of the very financial firms that pursued high-leverage, high-return, and high-risk strat-

${ }^{\dagger}$ Peter P. Weidenbruch, Jr., Professor of Business Law, Georgetown University Law Center, and Research Associate, European Corporate Governance Institute.

" William B. Johnson Professor of Law and Economics, University of Pennsylvania Law School, and Co-Director, Institute for Law and Economics, University of Pennsylvania. Our thanks to Jill E. Fisch, Joseph B. Frumkin, Jeffrey N. Gordon, Roy J. Katzovicz, Jonathan C. Lipson, David Millon, Stavros Panageas, Edward B. Rock, Mark J. Roe, Roberta Romano, José A. Scheinkman, Lynn A. Stout, Leo E. Strine, Jr., Jessica A. Wachter, David T. Zaring, and participants at workshops at Penn and Temple law schools for comments on earlier drafts, and to our research assistants, David Goldberg, William Mongan, and Nikki Sachdeva. 
egies and penalized those that did not. It is hard to see how shareholders, having played a role in fomenting the crisis, have a positive role to play in its resolution.

The prevailing legal model of the corporation strikes a better balance between the powers of directors and shareholders than does the shareholdercentered altermative. Shareholder proponents see management agency costs as a constant in history and shareholder empowerment as the only tool available to reduce them. This Article counters this picture, making reference to agency theory and recent history to describe a dynamic process of agency-cost reduction. It goes on to show that shareholder empowerment would occasion significant agency costs of its own by forcing management to a market price set under asymmetric information in most cases and set in speculative markets in which heterogeneous expectations obscure the price's informational content in others.

INTRODUCTION .655

I. FRAMING THE ISSUES: THE PREVAILING LEGAL MODEL, SHAREHOLDER EMPOWERMENT, AND AGENCY COSTS

A. The Economic Stakes: Trade-Off Versus Win-Win

1. The Trade-Off

2. The Win-Win

B. The Law-Reform Agenda.

C. Summary

II. SYSTEMIC RESPONSIVENESS

A. Corporate Governance and the Market for Corporate Control .. 677

B. New Blockholders 681

C. Cash Payouts. 685

D. Summary 687

III. SHAREHOLDER EMPOWERMENT AND ECONOMIC THEORY .688

A. Pricing Efficiency and the Case for Shareholder Empowerment

1. ECMH, CAPM, and the Value of a Share .............691

2. Implications for the Case for Shareholder Empowerment.

B. The Information Asymmetry Problem.............................. 696

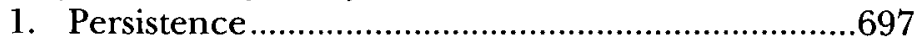

2. Evidence and Effects.........................................698

3. Idiosyncratic Volatility ......................................703

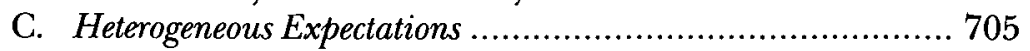

1. The Models.....................................................706

2. Implications for Business Policy and Corporate Governance .......................................709

a. Implications for Shareholder Voting ............... 709

b. Implications for Business and Investment Strategy 
c. Implications for the Legal Model of the Corporation............................................ 712

d. Controlling Shareholders Compared ............... 713

e. Implications for Management Compensation... 714

D. Summary ....................................................... 715

IV. SHAREHOLDERS, MANAGERS, MARKETS, AND THE

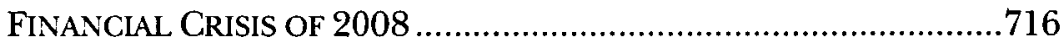

A. Financial Risk and Shareholder Inputs ............................717

B. The Changing Policy Context............................................724

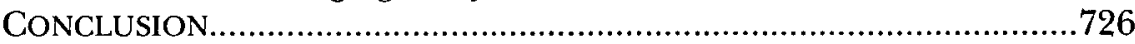

\section{INTRODUCTION}

In 2006, shareholder empowerment figured prominently in a wellpublicized law-reform agenda presented by the Committee on Capital Markets Regulation, a private group concerned about the competitiveness of U.S. capital markets. The Committee's report connected shareholder power to market control, reasoning that enhanced shareholder rights provide accountability and that accountability means lower agency costs, higher market prices, and, accordingly, a more competitive equity marketplace.' In addition, the Committee argued that strong shareholder rights invite more dependence on market discipline of managers and "go hand in hand with reduced regulation or litigation." Restating, "accountability" means market control, which means lower agency costs. The Committee thereby weighed in on corporate law's leading structural question: who should decide how best to maximize long-term value for the shareholders' benefit-the managers or the shareholders themselves? ${ }^{3}$ The

${ }^{1}$ See COMM. ON CAPITAL MKTS. REgULATION, INTERIM REPORT 93 (2006), available at http://www.capmktsreg.org/pdfs/11.30Committee_Interim_ReportREV2.pdf (arguing that enhanced shareholder rights in the areas of takeover defenses and remedy selection will reduce expected agency costs and incentivize entry in to U.S. public markets). The Committee's report focused on shareholder ratification of poison pills adopted by a staggered board, majority voting for boards of directors, shareholder access to the director nomination process, executive pay, and contractual alternatives to litigation. $I d$. at 16-18.

${ }^{2}$ Id. at 16 .

${ }^{3}$ This is often referred to as the debate over "shareholder primacy." But shareholder primacy has two aspects, the first going to the objective of the corporation and the shareholders' place as legal beneficiary, and the second going to the allocation of power within the corporation. This Article takes the first aspect as settled in favor of the shareholders and focuses on the second aspect. To avoid confusion, we avoid the term entirely, instead using the phrase "shareholder empowerment." 
question holds out a choice between a shareholder-driven, agency model of the corporation, guided by informational signals from the financial markets, and the prevailing legal model, which vests business decisionmaking in managers who possess an informational advantage regarding business conditions. The shareholder side contends that the prevailing model fails to provide a platform conducive to aggressive entrepreneurship and instead invites management self-dealing and conservative decisionmaking biased toward institutional stability. It looks to a shareholder community populated with actors in financial markets for corrective inputs. Unlike the managers, who are conflicted and risk averse, the shareholders come to the table with a pure financial incentive to maximize value. It is a high-stakes debate. For the Committee on Capital Markets Regulation, along with many other proponents of shareholder empowerment, the nation's global competitive fitness hangs in the balance.

Even so, shareholder proponents have shifted their emphasis in the wake of the financial crisis of 2008. ${ }^{4}$ Although "accountability" remains the ultimate goal, we hear fewer references to market control as the means to that end, presumably because it resonates equivocally in light of recent market failures. Proponents instead hold out the need to restore "trust." We illustrate this approach with the com-

${ }^{4}$ But see, e.g., Press Release, Council of Institutional Investors, CII Applauds Introduction of Shareholder Bill of Rights Act (May 19, 2009), available at http://www. cii.org/UserFiles/file/draft\%20press\%20release\%20schumer\%2005-19-09.pdf (quoting CII Chair and CALPers CIO Joseph A. Dear, who stated that the proposed act was needed "to promote market discipline and accountability").

${ }^{5}$ See The Causes and Effects of the Lehman Brothers Bankruptcy: Hearing Before the $H$. Comm. on Oversight and Gov't Reform, 110th Cong. 4 (2008) (statement of Nell Minow, Editor, The Corporate Library) (connecting shareholder power with the restoration of credibility); Luigi Zingales, The Future of Securities Regulation 2, 24-27 (Chi. Booth Sch. of Bus., Working Paper No. 08-27, 2009), available at http://ssrn.com/abstract= 1319648 (connecting trust and accountability, and contending that shareholder nominations will channel shareholder inputs to long-term value and deter managing to the market); Press Release, The Office of Senator Charles Schumer, Schumer, Cantwell Announce "Shareholder Bill of Rights" to Impose Greater Accountability on Corporate America (May 19, 2009), available at http://schumer.senate.gov/new_website/ record.cfm?id=313468 [hereinafter Schumer Press Release] (emphasizing the need to restore confidence through greater accountability and shareholder empowerment); $c f$. Roger Lowenstein, A Seat at the Table, N.Y. TIMES, June 7, 2009, (Magazine), at 11 (arguing that shareholder-nominated board members will cause shareholders to shift from a short-term view, in which exit is the primary means of expressing discontent, to a long-term view, in which "the less forceful, but more supple 'voice"" is used effectively). For a bank chairman's thoughts on the need to restore trust, see Stephen Green, Group Chairman, HSBC Holdings plc, Speech at the British Bankers' Association Annual International Banking Conference: Restoring Governance and Trust 3 (June 30, 2009), 
ments of former Securities and Exchange Commission (SEC) Chairman Arthur Levitt on the meltdown in the financial sector, ${ }^{6}$ which was still in its early phase when he wrote in the summer of 2008. For Levitt, the subprime collapse, the Bear Stearns implosion, and revelations of poor risk management at large financial firms had "injected a dangerously large degree of mistrust into the markets." ${ }^{7}$ He believes that managers and boards should have raised the alarm, and that enhanced shareholder voice, "[w]hile not a panacea, . . . would go a long way in helping to restore trust.",

The trust characterization resonates because it focuses on management culpability, and the managers who now have (or recently have had) to rely on government largesse do bear primary responsibility for the decisions that precipitated the financial crisis. Executive pay has become a flashpoint political issue as a result of the culpability designation, and the resulting popular picture is not pretty. ${ }^{9}$ Managers of financial companies appear as quick-buck artists who used their compensation schemes to siphon millions of dollars from companies on the brink of collapse. ${ }^{10}$ Their shareholders, as the primary bearers of losses incurred, emerge as victims along with the taxpayers. ${ }^{11}$

Blame for managers means sudden political traction for a longstanding law-reform agenda put forward by proponents of shareholder empowerment. We have already seen "say on pay" mandates imposed on TARP recipients, along with substantive constraints on

available at http://www.hsbc.com/1/PA_1_1_S5/content/assets/newsroom/090630_ speech_bba.pdf.

${ }^{6}$ See Arthur Levitt, Jr., Op-Ed., How to Boost Shareholder Democracy, WALL ST. J., July 1, 2008, at A17 (advocating for the repeal of prior SEC decisions in order to increase shareholder control and accountability).

${ }^{7}$ Id.

${ }^{8}$ Id.

9 See, e.g., Deborah Solomon \& Dan Fitzpatrick, Czar Blocks BofA Chief's Pay, WALL. ST. J., Oct. 16, 2009, at Al (reporting that the Treasury Department's "special master" for compensation objected to Bank of America CEO Kenneth D. Lewis's 2009 compensation, pushing Lewis to agree to forego salary for the year).

${ }^{10}$ Shareholder rights advocates often use this imagery. See, e.g., Lowenstein, supra note 5, at 11 ("[M]anagers cannot be trusted not to (grossly) overpay themselves...."); Schumer Press Release, supra note 5 ("[T] he leadership at some of the nation's most renowned companies took too many risks and too much in salary ...." (internal quotation marks omitted) (quoting Senator Schumer)); cf. Zingales, supra note 5, at 23-24 (noting the image, but arguing against direct regulation of pay).

11 See Shareholder Bill of Rights Act of 2009, S. 1074, 111 th Cong. $\$ 2$ (describing legislative findings and noting that a lack of accountability "led to the loss of trillions of dollars in shareholder value, losses that have been borne by millions of Americans who are shareholders through their pension plans, $401(\mathrm{k})$ plans, and direct investments"). 
modes and amounts of compensation. ${ }^{12}$ Broad "say on pay" mandates appear in prominent proposed legislation ${ }^{13}$ and in the Administration's reform agenda. ${ }^{14}$ There is also a high-profile SEC proposal to amend the proxy rules to require inclusion of shareholder board nominees in management proxy statements. ${ }^{15}$

While this reaction is perfectly understandable, it remains highly questionable as a policy matter. This Article states the contrary case, showing that the financial crisis, far from concluding the matter in the shareholders' favor, bolsters the case for the prevailing legal model. A shareholder-based agency model of the corporation sends management a simple instruction: in all circumstances, manage to maximize

12 See Emergency Economic Stabilization Act of 2008 (EESA), Pub. L. No. 110-343, $\$ 111$ (b) (2) (A), 122 Stat. 3765, 3777, amended by American Recovery and Reinvestment Act of 2009, Pub. L. No. 111-5, sec. 7001, §111, 123 Stat. 115, 516-20 (to be codified at 12 U.S.C. $\$ 5221$ ) (requiring sellers of troubled assets to have "limits on compensation that exclude incentives for senior executive officers of a financial institution to take unnecessary and excessive risks that threaten the value of the financial institution during the period that the Secretary holds an equity or debt position in the financial institution"). Subsequent Treasury guidelines require that for all TARP recipients executive base pay be limited to $\$ 500,000$ and that any incentive pay must be granted in the form of restricted stock, although these rules can be waived by shareholders except for those companies receiving "exceptional financial recovery assistance." Press Release, U.S. Dep't of the Treasury, Treasury Announces New Restrictions on Executive Compensation (Feb. 4, 2009), available at http://www.ustreas.gov/press/releases/tg15.htm; see also American Recovery and Reinvestment Act of 2009 secs. 7000-7002, $\S \S 111,109$ (a), 123 Stat. at 516-21 (amending EESA and limiting incentive payments to the CEO and the twenty next-highest-paid executives of large TARP recipients to one-half of the executive's salary (other than payments required under earlier contracts and restricted stock), prohibiting golden parachutes and defined "luxury" expenditures, and mandating "say on pay" votes). The SEC has proposed a rule implementing the "say on pay" mandate. See Shareholder Approval of Executive Compensation of TARP Recipients, 74 Fed. Reg. 32,474 (proposed July 8, 2009) (to be codified at 17 C.F.R. pt. 240) (amending proxy rules to help implement EESA requirements).

is See Shareholder Bill of Rights Act of 2009, S. $1074 \$ 3$ (amending prior acts to require that proxies "include a separate resolution subject to shareholder vote to approve the compensation of executives").

14 See U.S. DeP'T OF THE TREasury, Financial Regulatory Reform: A NEW FOUNDATION 29-30 (2009), available at http://www.financialstability.gov/docs/regs/ FinalReport_web.pdf (expressing the Department's intent to support increased transparency in compensation practices and supporting "say on pay" legislation).

15 Facilitating Shareholder Director Nominations, 74 Fed. Reg. 29,024 (proposed June 18,2009 ) (to be codified in scattered parts of 17 C.F.R.) (proposing to "require companies to include shareholder nominees for director in the companies' proxy materials" in certain circumstances). In addition, the New York Stock Exchange has amended its rules to eliminate broker discretionary voting for election of directors (for companies not registered under the Investment Company Act of 1940). N.Y. STOCK EXCH., LISTED COMPANY MANUAL $\$ 402.08(B)(19)$ (2009), available at http:// nysemanual.nyse.com/LCM/sections (follow "Section 4 " hyperlink). 
the market price of the stock. And that is exactly what managers of some critical financial firms did in recent years. They managed to a market that focused on their ability to increase observable earnings and, as it turned out, failed to factor in concomitant increases in risk that went largely unobserved.

Risk taking is at the heart of the capitalist system, but so is the incentive-compatible rule that the risk takers internalize not only the expected higher returns but also the expected higher systematic risk. For the financial institutions judged too big to fail, and apparently for others as well, risk internalization has not proven to be the case. The economic rescue's net costs amount to an externalization of the risks taken and an uninvited external shock to the political economy.

A negative implication follows for shareholder empowerment. If managers misunderstood the quantum of risks they were taking, then shareholders with more limited access to the relevant information certainly were no better informed and accordingly had no role to play in preventing externalization. Even as managers must shoulder the blame for the crisis, current complaints about management irresponsibility can legitimately be restated as complaints about management to the market. At the same time, management's risk aversion-its long-derided willingness to accept reduced risk in exchange for institutional stability - all of a sudden holds out advantages. Managers are risk averse because they fear losing their jobs in bankruptcy. Whereas bankruptcy is a natural element in the "winds of creative destruction," the U.S. Treasury.

The prevailing legal structure of the corporation holds out a robust framework. Corporate law has always performed a balancing act with management discretion and shareholder power. The balance, however, has always privileged the directors and their appointed managers in business policymaking because they are better informed than the shareholders and thus better positioned to take responsibility for both monitoring and managing the firm and its externalities. As between directors and shareholders, it is the directors who have the best access to information and are best able to serve as the monitors of the managers, increasing the likelihood of compliance with continuing

${ }^{16}$ Cf. William J. Abernathy \& Kim B. Clark, Innovation: Mapping the Winds of Creative Destmuction, 14 RES. POL'Y 3, 6 (1984) (describing Joseph Schumpeter's theory that innovation acts as a force of "creative destruction," reducing the value of existing competence and inspiring new growth). 
and emerging regulations. As between managers and shareholders, the managers are the ones who have the day-to-day knowledge of the company, its history, policies, opportunities, vulnerabilities, and challenges. The managers are likely to have the information and institutional perspective suited to anticipate points of conflict with the outside political economy and to formulate a responsive strategy. As long as they remain faithful, they are best suited to maximize the value of the corporation and thus the shareholders' residual claim.

The case outlined above must confront two responses from proponents of shareholder empowerment: First, shareholder incentives are correctly aligned and their business-policy preferences accordingly superior to those of conflicted managers; therefore, shareholder authority would reduce agency costs and increase the value of the corporation. Second, the efficiency of stock prices ameliorates the problem of information asymmetry and reliably communicates both the value implications of corporate policy to the shareholders and the business preferences of the shareholders to the managers. This Article rebuts this depiction of a win-win combination of shareholder power and market-sensitive management.

Part I frames the terms of debate. We ground our conceptual case for the prevailing legal model in Eugene Fama and Michael Jensen's description of the governance of publicly traded corporations. For Fama and Jensen, the prevailing legal model follows from an agencycost trade-off. The model divides the economic rights attached to the residual claim both from the power to set corporate policy, which goes to the managers, and from the responsibility to monitor the agents who execute the policy, which goes to the board. This separation follows from a natural allocation of interest, information, and expertise. It does so for the purpose of reducing the agency costs that would result if shareholders that are both dispersed and diversified had the power to impose policy inputs. Agency costs do result, but as an embedded and inevitable result of dispersed ownership.

Part II looks into the debate's economic stakes, pushing back against the shareholder claim that systemic slack results in enormous agency costs that can be reduced only through fundamental law reform. We ground our response in Michael Jensen and William Meckling's seminal theory of agency costs and its projection of a dynamic, market-based process of agency-cost reduction. The shareholder proponents depict agency costs as a static, ahistorical constant. We question this picture from a historical perspective, asserting that even though agency costs tied to shareholder disempowerment had a 
moment of high salience during the 1980s, their importance diminished in subsequent years. The diminution followed from a dynamic pattern of response to underlying market forces, both inside boardrooms and outside in the markets. Inside, management reoriented itself and adopted key points from the shareholder agenda into corporate business plans, facilitating mergers and restructurings and stepping up cash payouts to shareholders. Outside, shareholders got stronger. The rationally apathetic investor waned as the institutional shareholder voice rose in volume and increasingly independent boards of directors got into the habit of listening. In our view, the shareholder case emerges denuded of urgency.

Part III steps into the brave new world projected by the shareholder proponents, to see how things will work. We draw on financial economic theory to identify serious problems under the new regime. The claim of market price robustness rests on the assertion that recent advances in the stock market's informational efficiency render fluid, unaffiliated groups of shareholders well enough informed to make wise choices on many corporate matters. Unfortunately, the stock price has two material shortcomings when viewed as a source of day-to-day instructions for business policy: First, stock prices are not fully informed because of informational asymmetries enjoyed by managers. Second, stock prices can be influenced by speculative factors unrelated to fundamental value, factors highlighted in the recent finance literature on heterogeneous expectations. Serious risks of unintended negative consequences follow when management decisions are directed to stock price reactions. It has long been known that financial markets display more volatility than the volatility in the underlying economy could ever justify. Asking managers to manage to the market could inject that higher degree of financial market volatility into the real economy.

Part IV turns to the financial crisis. The fact that management bears primary responsibility for the crisis does not by itself effect a policy connection between increased shareholder power and regulatory reform. A connection obtains only if increased shareholder power would have imported more effective risk management in advance of the crisis. No plausible grounds exist for making such a case. If anything, the managers responsible had incentives too closely aligned with those of their shareholders due to equity incentive compensation. Compensation, accordingly, is the topic on which the crisis holds out a lesson for corporate governance. If trust is to be restored, equity incentive plans must be restructured to discourage manage- 
ment to the market. Shareholder empowerment, far from getting us to that result, would get in the way.

\section{Framing the Issues: The Prevalling Legal Model, SHAREHOLDER EMPOWERMENT, AND AGENCY COSTS}

The prevailing legal model of the corporation privileges the decisionmaking authority of the board of directors. The board, in the classic expression, wields "original and undelegated" ${ }^{17}$ powers that follow directly from the organizational form provided by the law rather than from a delegation of authority from the shareholders. Even though the shareholders elect the board, they have no right to tell it what to do. They can only proceed indirectly, by removing it ${ }^{18}$ or replacing it at the next annual meeting. As a legal matter, directors are not agents of the shareholders.

Proponents of shareholder empowerment propose an alternative regime of shareholder choice regarding matters of business policy. Under their contrasting model of the corporation, the shareholders emerge as principals in an agency relationship. ${ }^{19}$ From this point of view, the board's decisionmaking power stems from the shareholders' delegation of that power. It follows that what the shareholders delegate they should also be able to withdraw.

This Article makes a policy case to support the present legal allocation of power. This Part lays out the basic terms of the debate in which we intervene. We begin, in Section A, by contrasting the economic framework in which we ground our case with the economic framework that undergirds the case for shareholder empowerment. Section B lays out shareholder proponents' law-reform agenda.

\section{A. The Economic Stakes: Trade-Off Versus Win-Win}

The shareholder case has historical roots in The Modern Corporation and Private Property, by Adolf Berle and Gardiner Means. ${ }^{20}$ Berle and

\footnotetext{
${ }^{17}$ People ex rel. Manice v. Powell, 94 N.E. 634, 637 (N.Y. 1911) (internal quotation marks omitted) (quoting Hoyt v. Thompson's Ex'rs, 19 N.Y. 207, 216 (1859)).

${ }^{18}$ See DEL. CODE ANN. tit. 8, §141(k) (2001) (providing for removal of the boards of directors of Delaware corporations).

${ }^{19}$ See, e.g., Henry Hansmann \& Reinier Kraakman, The End of History for Corporate Law, 89 GEO. L.J. 439, 439-40 (2001) (asserting that legal regimes worldwide have converged on corporate law systems characterized by "shared ownership by investors" and "delegated management" to a board).

${ }^{20}$ Adolf A. Berle, JR. \& Gardiner C. MEANS, THE MOdERn Corporation and Private Property (William S. Hein \& Co., Inc. 1982) (1932).
} 
Means famously showed that ownership and control of public corporations had separated, charging that resultant management power needed significant substantive constraint, constraint that earlier in history had been exercised by shareholder-owners. ${ }^{21}$

We base our case for the prevailing legal model on Eugene Fama and Michael Jensen's rebuttal of the Berle and Means diagnosis. ${ }^{22}$ Fama and Jensen reframed the separation of ownership and control as a rational allocation of risk-bearing and decisionmaking functions. Expertise, access to information, and complexity emerge as neutral, economic explanations for what Berle and Means described in economic terms as intrinsically problematic and in political terms as illegitimate management empowerment.

\section{The Trade-Off}

Fama and Jensen substitute contract for property as the mode of analysis and ask why public corporations have survived in history. They suggest that organizational contracts must perform two functions: (1) the allocation of the residual claim, and (2) the allocation of decision rights. ${ }^{29}$

In Fama and Jensen's depiction, shareholders contract for the right to the net cash flows, thus taking the residual claim. Decision management and decision control, in contrast, go inside the organization, subject to shareholder retention of the right to vote for the board and matters reserved for their ratification. ${ }^{24}$ This holds out an

${ }^{21}$ See id. at 124 ("The concentration of economic power separate from ownership has, in fact, created economic empires, and has delivered these empires in to the hands of a new form of absolutism, relegating 'owners' to the position of those who supply the means whereby the new princes may exercise their power.").

${ }^{22}$ See Eugene F. Fama \& Michael C. Jensen, Separation of Ownership and Control, 26 J.L. \& ECON. 301, 301-02 (1983) [hereinafter Fama \& Jensen, Separation] (rebutting Berle and Means's analysis by arguing that organizations where ownership and control are separated survive because they benefit from specialization of these roles and are able to control agency problems by separating "the ratification and monitoring of decisions from initiation and implementation of the decisions"); see also Eugene F. Fama \& Michael C. Jensen, Agency Problems and Residual Claims, 26 J.L. \& ECON. 327, 331-32 (1983) [hereinafter Fama \& Jensen, Agency Problems] (recapping the thesis of Fama \& Jensen, Separation of Ownership and Control, supra, and noting that devices for separating these roles include "decision hierarchies," boards of directors, and "incentive structures that encourage mutual monitoring among decision agents").

${ }^{23}$ Fama \& Jensen, Separation, supra note 22, at 302 . Note that this two-part division of functions precisely identifies the two contested zones in corporate law's political economy.

${ }^{24}$ See id. at 313 (explaining that shareholders vote on "auditor choice, mergers, and new stock issues" in addition to board membership). 
economic advantage: the residual risk holders "are not required to have any other role in the organization." ${ }^{25}$ This frees them to specialize in risk bearing, leaving others to specialize in initiating and implementing business decisions and in monitoring their effectiveness. ${ }^{26}$ The alternative of cutting the shareholders into business decisionmaking could be costly: "[M]ost of the diffuse residual claimants are not qualified for roles in the decision process." ${ }^{27}$ After all, wealth and willingness to bear risk do not by themselves assure needed skills. ${ }^{28}$ It follows that the delegation of decision management and control to actors inside the corporation is efficient. ${ }^{29}$

Decision rights, thus sent inside the organization, are split between two groups. The powers of initiation and implementation go to management. $^{30}$ Thus management is separated from residual risk bearing. The reason is agency-cost reduction. Given a complex business organization with knowledge diffusion, business decisionmaking should go to agents with relevant knowledge. ${ }^{31}$ At the same time, controls need to be imposed to protect the residual claimants from expropriation by the managers. This second aspect of agency-cost reduction calls for having a separate decision controller to monitor and ratify management decisions. ${ }^{32}$ The two decision functions, management and monitoring, must be separate "almost by definition." ${ }^{33}$ As a result, a board of directors that includes outsiders performs the monitoring function. ${ }^{34}$ The board retains "ultimate control over internal agents" and their decisions ${ }^{85}$ and stands in for the classical ownerentrepreneur $^{36}$ of Berle and Means. Backstopping the board as agen-

${ }^{25}$ Fama \& Jensen, Agency Problems, supra note 22, at 328.

${ }^{26} I d$. at 330 .

${ }^{27}$ Fama \& Jensen, Separation, supra note 22, at 309.

${ }^{28}$ See id. at 312 (commenting that, because managerial skills are not necessarily tied to wealth or willingness to bear risk, specialization enhances a complex organization's ability to adapt to changes in the economic environment and lowers the cost of risk-bearing services).

${ }^{29} I d$. at 309 .

${ }^{30}$ See id. at 303-04 (defining the activities involved in decision initiation and implementation).

S1 See id. at 307-08 (noting that this model reduces agency costs).

Id at 308-09.

33 Id. at 304.

${ }^{34} \mathrm{See} i d$. at 313,315 (discussing the incentives of outside directors).

${ }^{35} I d$. at 313.

${ }^{36}$ See id. at 309 ("Separation and diffusion of decision management and decision control-in effect, the absence of a classical entrepreneurial decision maker-limit the 
cy-cost controllers are a host of public and private external monitorsthe courts and regulatory agencies on the public side, and the stock market and the takeover market on the private side. ${ }^{37}$

What becomes of ownership in Fama and Jensen's contractual model? The model, rather than separating it from control, divides it up along with control. The classical owner-entrepreneur performs all three of the functions they identify-she sets business policy, monitors corporate agents, and bears the residual risk. Fama and Jensen in effect take these ownership incidents and distribute them across the organization. The shareholders emerge as owners-in-part, bearing the residual risk and, as voters, sharing in control at a step removed from business decisionmaking and direct monitoring. It follows that management and the board share in ownership. This sharing of ownership functions implies nothing radical; it is just a contractual adjustment of the classical model that accounts for the evolution of corporate law and practice during the twentieth century.

Thus Fama and Jensen rebut the notion that corporate governance is dysfunctional because a traditional shareholder-owner is absent. But the rebuttal, effective though it may be, does not by itself determine the outcome of today's contest between the shareholderdirected agency model and the prevailing legal model. It does, however, clear noise from the screen, facilitating a meaningful statement of the policy issue. The noise comes from the conceptual legacy of unitary ownership and the teaching that shareholders are owners who are natural principals in an agency relationship with corporate management. Once the noise is filtered out and the division of ownership is recognized, the question becomes whether the allocation of authority in public corporations makes economic sense. Fama and Jensen answer in the affirmative for the reasons just given.

\section{The Win-Win}

The shareholders' basic claims can be accessed through Henry Hansmann and Reinier Kraakman's identification of two touchstone points that ground a general consensus in their favor: first, "ultimate control over the corporation should rest with the shareholder[s]," and

power of individual decision agents to expropriate the interests of residual claimants.").

Id. at $312-13$. 
second, the market price of the corporation's stock should provide "the principal measure of its shareholders' interests."

"Ultimate control" takes us to an agency framework ${ }^{39}$ favoring shareholder inputs. The supporting economic case focuses on agency costs and incentives. All other things equal, agency-cost reduction enhances value, and enhanced principal control can conceivably lower agency costs. ${ }^{40}$ So the question is whether shareholders, as principals, are well suited to provide value-enhancing inputs, or, as Fama and Jensen asserted, are not well suited.

The suitability case begins with shareholder incentives: their capital investment ${ }^{41}$ in the residual interest lends them an undiluted, pure financial incentive to maximize the value of the firm. ${ }^{42}$ From an incentive point of view, shareholders contrast favorably with managers and independent directors, whose incentives are comprised by interests in compensation and job retention.

The question then becomes whether these pure shareholder incentives can be harnessed by the governance system despite the fact that dispersed, diversified shareholders labor under information asymmetries and lack business expertise. Hansmann and Kraakman's second proposition-that the market price of the stock provides the "principal measure" of the shareholder interest-holds out the means to this end. If the stock price provides an objective and accurate

${ }^{38}$ Hansmann \& Kraakman, supra note 19, at 440-41.

${ }^{39}$ The phrase "ultimate control" is imprecise. The assertion in the text reflects our interpretation. The legal model already vests the franchise in the shareholders and directs the board to manage in their interests. Arguably, this amounts to an allocation of "ultimate control." Hansmann and Kraakman accordingly imply more in the way of shareholder authority. To see why, compare Hansmann and Kraakman's conception to that of Fama and Jensen, who assign "ultimate control" to the board of directors, subject to the shareholder vote. See Fama \& Jensen, Separation, supra note 22, at 313. This would not suffice for Hansmann and Kraakman, for whom "ultimate control" at a minimum means shareholder choice on tender offers, as they consider trustbased outcomes favoring management discretion to be inefficient. See Hansmann \& Kraakman, supra note 19, at 467. Even as today's shareholder agenda goes much farther, the term "ultimate control" easily accommodates it.

${ }^{40}$ See COMm. ON CAPITAL MKTS. Regulation, supra note 1, at 16 (asserting that "[s]hareholder rights serve the critical function of reducing ... agency costs" and that inadequate shareholder rights cause shares to trade at a discount to fundamental value).

${ }^{41}$ See Bengt Holmstrom \& Steven N. Kaplan, Corporate Governance and Merger Activity in the United States: Making Sense of the 1980s and 1990s, J. ECON. PERSP., Spring 2001, at 121,138 ("[I]f resources are to shift ... the market may have a role to play in funneling capital toward the new companies.").

${ }_{42}$ See Hansmann \& Kraakman, supra note 19, at 449 ("[I]f the control rights granted to the firm's equity-holders are exclusive and strong, they will have powerful incentives to maximize the value of the firm."). 
measure of the purely motivated shareholder directive to maximize value, it provides the best source of instructions for governance and business policy. After all, it is in the financial market where shareholders, using the Holmstrom and Kaplan metaphor, "put their money where their mouth is." ${ }^{43}$ From this it follows that a manager-agent with correct incentives should manage to the market price. ${ }^{44}$

Thus do the shareholder proponents contemplate a species of market control. ${ }^{45}$ They want the market price-which is, after all, set by shareholders investing at the margin-to be the ongoing and determining source of shareholder input. It bids those managers who are effective agents to manage to the stock market in formulating business policy, thereby accessing the high-quality instructions embedded in stock market prices. With the market price as the management yardstick, value-enhancing opportunities to merge, sell, or dissolve will no longer be frustrated by the managers' desire to hold on to control; resources will no longer be misdirected to suboptimal executive compensation plans; and governance arrangements will import appropriate constraints and incentives. ${ }^{46}$ Managing to the market price also is thought to import administrative coherence, because the yardstick provides a means with which to evaluate management performance. ${ }^{47}$

Value maximization pursued with a long-term time horizon is said to follow. ${ }^{48}$ Here the proponents refer to basic principles of valuation,

${ }^{43}$ Holmstrom \& Kaplan, supra note 41, at 138; see also George W. Dent, Jr., Academics in Wonderland: The Team Production and Director Primacy Models of Comporate Governance, 44 HOUS. L. REv. 1213, 1225 (2008) ("Although share prices do not exactly match fundamental value, no measure is better.").

${ }^{44}$ This Article continues a line of analysis that begins in Michael L. Wachter, Takeover Defense When Financial Markets Are (Only) Relatively Efficient, 151 U. PA. L. REV. 787 (2003).

${ }^{45}$ See COMm. ON CAPITAL MKTS. REgulation, supra note 1, at 16 (asserting that strengthened "shareholder rights go hand in hand with reduced regulation [and] litigation").

${ }^{46}$ See Lucian Arye Bebchuk, The Case for Increasing Shareholder Power, 118 HARV. L. REV. 833, 840, 850 (2005) (noting that, in the absence of shareholder intervention, management tends not to adopt "game-ending decisions" because such decisions also end the managers' control).

${ }^{47}$ See Holmstrom \& Kaplan, supra note 41, at 138-39 (explaining that long-term management effects, especially in times of change, are difficult to measure absent share prices).

${ }^{48}$ See Hansmann \& Kraakman, supra note 19, at 451 ("The ability of standardmodel firms to expand rapidly in growth industries is magnified... by access to institutional investors and the international equity markets .... Over time, then, the standard model is likely to win the competitive struggle on the margins.... As the pace of technological change continues to quicken, this competitive advantage should continue to increase."). 
which teach that long-term value is impounded in the present market price. $^{49}$ It follows that managing to the market price is incentive compatible with regard to the time horizon because both short-term and long-term investors have incentives to maximize long-term value. ${ }^{50}$

Shareholder proponents do not deny that the market price is set under conditions of information asymmetry and thus is not fully informed. ${ }^{51}$ The implied assertion is that any resulting divergence between market price and fundamental value will not hold out perverse effects, given management to the market price. An ameliorating factor has also been noted: some studies show that market prices have become better informed over the past half century. ${ }^{52}$ The information gap between those inside and outside of the corporation has narrowed, due in part to stricter mandatory disclosure requirements and in part to more liquid markets and a larger sector of information intermediaries. ${ }^{53}$

Summing up, shareholder proponents seek to reform the prevailing legal model of the corporation (or what might be called the "Fama-Jensen corporation") to ensure that shareholder inputs directly impact both business decisionmaking and monitoring. The supporting theoretical case rests upon three assumptions: first, that information asymmetries can be ignored (or alternatively, that managers cannot be trusted to use their superior knowledge in the best interest of the corporation); second, that business instructions following from pure financial incentives have agency-cost reductive effects; and, third, that the market price accurately communicates these instructions.

${ }^{49}$ See Bernard Black \& Reinier Kraakman, Delaware's Takeover Law: The Uncertain Search for Hidden Value, 96 Nw. U. L. REV. 521, 522 (2002) (explaining that intrinsic or "hidden" value can be assessed by a board but is invisible to shareholders).

${ }^{50}$ In the view of shareholder proponents, accountability suffers under the prevailing regime, leading to inefficient regulatory responses, including shareholder litigation. See COMM. ON CAPITAL MKTS. REGULATION, supra note 1, at 16,93-96. Therefore, systemic reform designed to facilitate shareholder intervention is appropriate because the inherited model affords management discretionary space to disregard the price directive.

${ }^{51}$ See Jeffrey N. Gordon, The Rise of Independent Directors in the United States, 1950 2005: Of Shareholder Value and Stock Market Prices, 59 STAN. L. REv. 1465, 1548-63 (2007) (discussing the factors that have narrowed the scope of information asymmetry and thereby increased stock price information, but not suggesting perfect symmetry).

${ }^{52}$ For a description of the empirical literature, which focuses on an increase in idiosyncratic volatility, see infra notes $156-59$ and accompanying text.

${ }^{53}$ See Gordon, supra note 51, at 154863 (attributing stock prices' increased information value to SEC and Financial Accounting Standards Board (FASB) disclosure regulations, as well as to the rise in investment analysts and information-dissemination mechanisms). 


\section{B. The Law-Reform Agenda}

The shareholders' law-reform agenda took shape in response to the takeover wars of the 1980s. State lawmakers and state courts, in particular the Delaware courts, responded to the outbreak of hostile activity by restating and reinforcing the legal model's allocation of authority to management. ${ }^{54}$ The shareholder case coalesced as a protest against that outcome, and the context was ideally suited to the shareholder position. Recall that Fama and Jensen defended the legal model on the assumption that a vigorous market for corporate control operated as a check on subpar managers. ${ }^{55}$ If courts and legislatures had impaired that market's operation, the impairments needed to be removed. Moreover, the takeover context minimized the importance of the shareholders' debilities respecting information and expertise. In the information-enriched environment created by the disclosure requirements of a contested battle for control, shareholders were deemed informed enough to choose rationally between the value of two or more competing corporate strategies. ${ }^{56}$

Furthermore, shareholders were seen as having been on the right side of the era's valuation questions. The capital markets emerged

${ }^{54}$ This response raised questions about the terms of fiduciary duty. It took a decade and four famous cases before the Delaware courts delivered a definitive answer respecting the scope of the fiduciary duty. See Unitrin, Inc. v. Am. Gen. Corp., 651 A.2d 1361,1388 (Del. 1995) (ruling that refusal to redeem a poison pill survives review if it is neither "preclusive" nor "coercive" and falls within a "range of reasonableness"); Paramount Commc'ns, Inc. v. Time Inc., 571 A.2d 1140, 1154 (Del. 1989) (sustaining the "just say no" defense based on a business plan implemented by the board of directors); Moran v. Household Int'l, Inc., 500 A.2d 1346, 1351-57 (Del. 1985) (sustaining the poison pill as a structural matter and applying Unocal scrutiny); Unocal Corp. v. Mesa Petroleum Co., 493 A.2d 946, 955-56 (Del. 1985) (applying proportionality scrutiny to management defense tactics). When the answer finally came, trust trumped agency, forcing hostile offerors to resort to the shareholder franchise in the form of a proxy fight for board control in order to put to the shareholders the choice between the offer price and management's claim that its business plan held out greater value on a longterm basis. That is, the board was left with the power to block offers to protect the business plan, thereby remitting the exercise of shareholder choice not to the market for shares but to the exercise of the franchise. See Ronald J. Gilson \& Alan Schwartz, Sales and Elections as Methods for Transferring Corporate Control, 2 THEORETICAL INQUIRIES L. 783,788 (2001) (emphasizing that, because of the ubiquity of the poison pill, corporate control changes occur principally by election rather than through the market).

${ }_{55}$ See supra text accompanying notes $30-37$.

${ }^{56}$ The Delaware courts disagreed even so, channeling the contested control transaction into the even richer information environment of the proxy contest. See Paramount Comme'ns, 571 A.2d at 1154-55 (permitting a corporation's board of directors to forgo unsolicited tender offers it perceives as threats to corporate policy despite shareholder support, thereby forcing a bidder to use alternative means of acquiring control). 
from the 1980s with an enhanced reputation as drivers of productivity. The era's corporate restructurings were deemed to have been a productive success. It followed that capital markets had a comparative advantage over appointed managers in effecting structural reforms necessitated by deregulation and technological change..$^{57}$ Firms tend to be experts in existing technologies, products, and processes. Markets came to be thought to have the advantage when it comes to recognizing the implications of new technologies, products, and processes-the markets move the capital to higher-valuing users who then put the capital into more productive projects. ${ }^{58}$

Shareholder empowerment emerged from the takeover era as the leading issue in corporate law, with a consistent consensus in its favor. The list of agenda items continued to grow during the period of institutional adjustment that followed. The shareholders, dissatisfied with the legal outcome and led by now-dominant institutions, lost their passivity. "Governance" became a zone of ongoing engagement between managers, institutional shareholders, and a new class of professional intermediaries. Independent boards of directors assumed greater institutional salience. ${ }^{60}$

Even so, shareholder empowerment remained elusive ${ }^{61}$ and so emerged as the focus of a law-reform agenda. If the shareholders could

${ }^{57}$ See Holmstrom \& Kaplan, supra note 41, at 122 ("The real drivers behind the increased dominance of capital markets ... can be traced to deregulation ... and to new information and communication technologies...."). We note that while Holmstrom and Kaplan expect the 1980s experience of market advantage to persist over time, they also acknowledge the possibility of changed conditions under which market price guidance could lose its productive quality. See id. at 140-41 (suggesting that if stock markets slow, reliance on them may also decrease).

${ }^{58}$ See id. at 137-38 ("Markets are more effective than managers when it comes to moving capital from declining industries to emerging industries."); cf. Hansmann \& Kraakman, supra note 19, at 450-51 (noting that shareholder input will favor aggressive development of new product markets and abandonment of inefficient investments).

${ }^{59}$ Shareholders can be counted on to vote against antitakeover amendments and in favor of redeeming poison pills. See Marcel Kahan \& Edward B. Rock, How I Learned to Stop Worrying and Love the Pill: Adaptive Responses to Takeover Law, 69 U. CHI. L. REV. 871, 898 (2002) (noting that, when possible, shareholders prevented the adoption of "takeoverinhibiting charter amendments" while voting in favor of proposals to redeem poison pills).

${ }^{60}$ See Gordon, supra note 51, at 1511 (noting the "increasingly tight link between the independent board and the priority of shareholder value").

${ }^{61}$ The post-takeover era began with a vision of direct institutional investor control through aggressive use of the shareholder franchise. See Bernard S. Black, Shareholder Passivity Reexamined, 89 MICH. L. REV. 520, 525, 585-89 (1990) (discussing shareholder monitoring as a concept that had not yet come to fruition and analyzing factors that influence whether shareholders remain apathetic or not). It was hoped that institutional holdings had reached a level of concentration that would render collective ac- 
not surmount collective action problems themselves, then law reform directed at lowering the costs and expanding the payoffs of shareholder intervention made sense. Today's shareholder law-reform agenda serves these dual purposes.

Proposals on the agenda fall into two categories. The first, a narrower category, accepts the existing legal model in its broad outline and focuses on process reforms designed to expand the range of shareholder choices in the election process and to facilitate shareholder contests. The second type would give the shareholders the option to legislate their way out of the prevailing model, to an agency model holding out direct control of business policy. Cost concerns are present in both categories. Some reforms are designed to enhance the impact of existing low-cost activist strategies like "just vote no" campaigns. All of the rest include transfers from the corporate treasury to intervening shareholders.

The list of improvements proposed for the present election system is lengthy. The first items are designed to facilitate rejection of selected candidates and protest voting. These include majority (as opposed to plurality) voting and confidential voting, both of which have already been adopted voluntarily by many corporations. ${ }^{62}$ Reformers

tion barriers surmountable, with U.S. institutions stepping into the role played by blockholders in other governance systems. See, e.g., Ronald J. Gilson \& Reinier Kraakman, Reinventing the Outside Director: An Agenda for Institutional Investors, 43 STAN. L. REV. 863, 884-88 (1991) (suggesting that institutional investors could organize on a subscription basis and fund correctly incentivized candidates for board seats). But no such movement to self-help by spontaneous order occurred. Far from yielding, collective action barriers instead emerged much reinforced in the new environment. The free-rider problem continued to discourage investment managers from incurring the costs of governance challenges-gains that must be shared with competitors who do not share the costs do not advance investment managers' careers. See Jill E. Fisch, Relationship Investing: Will It Happen? Will It Work?, 55 OHIO ST. L.J. 1009, 1019-25 (1994) (discussing the free-rider problem as disincentivizing investors from monitoring because the benefits spread to competitive investors but the cost is only borne by the monitor); Edward B. Rock, The Logic and (Uncertain) Significance of Institutional Shareholder Activism, 79 GEO. L.J. 445, 473-74 (1991) (acknowledging that money managers have no selective incentives to actively improve diversified funds because doing so would simultaneously benefit the managers to whom they are compared).

At the same time, many fund advisors sell services to managers, importing an independent business reason to stay cooperative. See, e.g., Stephen M. Bainbridge, Director Primacy and Shareholder Disempowerment, 119 HARv. L. REv. 1735, 1751-54 (2006) (describing the incentive problems of financial institutions). Finally, mutual fund investors can redeem at any time, inhibiting investment in large, illiquid blockholder positions that would carry boardroom influence.

62 See Claudia H. Allen, STUdy OF MAjority VOting In DiRECTOR EleCtions, at viii (2007), http://www.ngelaw.com/files/upload/majoritystudy111207.pdf (demonstrating that majority voting has become standard practice among large public companies). 
want shareholders to have the option of a "no" vote (as opposed to the present "withhold" vote expression of negativity) and a right to replace all incumbents every two or three years. ${ }^{63}$ Other provisions hold out more in the way of power shifting. They would clear a way for shareholder nomination of board candidates, not only by opening access to the proxy statement but by providing for reimbursement of solicitation expenses. ${ }^{64}$

The second legislative category is more radical. The shareholders already have the power to amend the bylaws under state codes. ${ }^{65}$ But, even cabined in a tight zone of process-based subject matter, ${ }^{66}$ the power has been unexercised because shareholders, while they do have the power to put a bylaw amendment to a shareholders' meeting, have neither access to management's proxy statement nor state law power to trump contrary board-adopted bylaws. The reformers would grant both. ${ }^{67}$

At the same time, there are definite limits on what can be accomplished through bylaw amendment. Bylaws are limited to process matters and cannot surmount the reservation to the board of the power to manage the business, a reservation read broadly by the Delaware courts. ${ }^{68}$ Only a charter amendment can delimit the board's powers, ${ }^{69}$ and state corporate codes accord the board agenda control

${ }^{63}$ See Lucian A. Bebchuk, The Myth of the Shareholder Franchise, 93 VA. L. REV. 675, $700-04$ (2007) (suggesting these election reforms as part of a broader reform scheme to make directors accountable to shareholders).

${ }^{64}$ See id. at 696-700 (noting that threshold requirements would be needed). For the SEC's recent proposal, see Facilitating Shareholder Director Nominations, 74 Fed. Reg. 29,024 (proposed June 18, 2009) (to be codified in scattered parts of 17 C.F.R.), and supra note 15 and accompanying text.

${ }^{65}$ See, e.g., DEL. CODE ANN. tit. 8, $\S 109$ (2001) (granting shareholders the power to adopt, amend, or repeal bylaws even when directors share this power).

${ }_{66}$ See CA, Inc. v. AFSCME Employees Pension Plan, 953 A.2d 227, 231-40 (Del. 2008) (answering questions certified from the SEC regarding a proposed bylaw that improperly sought to "remove the subject of election expense reimbursement" from the board's discretion).

${ }^{67}$ See Bebchuk, supra note 63, at 707-11 (arguing that shareholder-adopted bylaws should be facilitated while boards' power to adopt bylaws should be constrained). The SEC's current proposed rules include a limited bylaw access provision, keyed to "shareholder proposals that would amend, or that request an amendment to, a company's governing documents regarding nomination procedures or disclosures related to shareholder nominations ...." Facilitating Shareholder Director Nominations, 74 Fed. Reg. at 29,024.

${ }_{68}$ See CA, Inc., 953 A.2d at 232 (noting that shareholders lack the broad management power statutorily allocated to the board of directors).

${ }^{69}$ See DEL. CODE ANN. tit. $8, \S 242$ (a) (2) ("[A] corporation may amend its certificate of incorporation ... [t]o change, substitute, enlarge or diminish the nature of its business or corporate powers and purposes...."). 
over charter amendments. ${ }^{70}$ The agency reformers accordingly would open the door to shareholder-initiated charter amendments and accord power to initiate a change of jurisdiction of incorporation, with expense reimbursement. ${ }^{71}$ They contemplate that once the door is opened, shareholders can allocate to themselves the power to force a sale or liquidation of the firm, ${ }^{72}$ or to force a large dividend (and the leveraged financing thereof) or a subsidiary spin-off. ${ }^{73}$ Present proposals respecting business policy stop at this point. But we note an implicit open end: once any door to the reversal of board business judgment is opened, there will be no principled basis for containing shareholder mandates respecting business policy.

Finally, "say on pay" initiatives would similarly allow the shareholders to cross the line to control of business policy, but in ratification mode and on a mandated annual basis. Here the idea is to put the top executives' total compensation package to the shareholders for an up/down advisory vote."

\section{Summary}

The shareholders' reform agenda reflects their view that the prevailing model is out of date. By hypothesis, it remained defensible only so long as collective action problems rendered shareholder exercise of discretionary powers infeasible. But, as we have seen, concentrated institutional shareholdings have not by themselves removed this barrier. Accordingly, if the firm is to be reconstituted along agency lines, ${ }^{75}$ the shareholder collective action problem must first be solved by changing the terms of shareholding itself through a system of subsidies for activists. With that accomplished, the shareholders would get the power to opt out of the prevailing model on a firm-by-firm basis.

${ }^{70}$ See id. $\S 242$ (b) (1) ("Every amendment authorized by subsection (a) . . . shall be made ... in the following manner: ... [the] board of directors shall adopt a resolution setting forth the amendment proposed ....").

7 See Bebchuk, supra note 46, at 865-70 (suggesting that shareholders should be empowered to change things like the corporate charter and the state of incorporation).

${ }^{72}$ See id. at 895-901 (addressing the effects on agency costs of shareholder power to participate in "game-ending" decisions).

${ }^{73}$ See id. at 901-08 (analyzing the impact of shareholder power to make "scalingdown" decisions).

74 Initiatives presently on Washington reform agendas fall into the first, narrower category addressed to the shareholder franchise. See supra note 12 and accompanying text.

${ }^{75}$ See Black, supra note 61 , at 608 (noting that shareholder voice is an idea that has never been tried, rather than an idea that has failed). 
Significantly, the shareholder proponents do not anticipate that these reforms would open the door to hundreds of issue-based proxy contests. They instead point to an in terrorem effect. They project that the threat of shareholder intervention by itself will influence management conduct, forcing managers to focus on the stock price in order to avoid triggering destabilizing and disempowering shareholder action. $^{76}$

The projection is fair. ${ }^{77}$ But therein lies the problem. The shareholder proponents dismiss the prevailing legal model too quickly,

${ }^{76}$ See Bebchuk, supra note 46 , at 878 ("Introducing the [shareholder] power to intervene would induce management to act differently in order to avoid shareholder intervention.").

${ }^{77}$ In making this projection, shareholder proponents effectively respond to a point made by their critics, who warn that pure financial incentives posited by shareholder proponents will not obtain efficiency in all cases and that empowered activists may have private agendas. See Iman Anabtawi, Some Skepticism About Increasing Shareholder Power, 53 UCLA L. REv. 561, 586-93 (2006) (explaining how the interests of certain types of shareholders may differ from the interests of others). Since the bite lies in the threat, any problems of self-dealing can be dealt with by fiduciary law, and any incentive misalignments in actual contests will come out and impact the vote. Note also that if the bite lies in the threat, any shareholder incentive problems will be minimal because the shareholders who actually wield the power will be the market price setters, actors who do indeed act with undiluted incentives to maximize value.

The critics make two additional points. First, they project governance incoherence in the move from oligarchic to democratic governance, citing information asymmetries and conflicting interests within the group of newly empowered constituents. See, e.g., Bainbridge, supra note 61, at 1745 (citing KeNNETH J. ARROW, THE LimITS OF ORGANIZATION 68-70 (1974)) (arguing that authority-based decisionmaking structures, grounded in central agencies empowered to make binding decisions, are necessary when the organization's constituencies suffer from information asymmetries and have differing interests). Second, they predict that shareholder empowerment will impose a short-term time horizon with consequent perverse effects. See, e.g., Anabtawi, supra, at 579-80 (noting how pressure from short-term shareholders can cause companies to neglect long-term focus).

Shareholder proponents similarly rely on the market price to rebut the first criticism. They pose the market price as the focal point for decisionmaking, thereby obviating any coherence problem. If the market price is indeed suited to guide business policymaking, the shareholder proponents win this point. Emphasis accordingly needs to be directed away from theories of government to financial economics, where the inquiry should focus on the interplay between information asymmetry, investor expectations, and market pricing. We conduct this inquiry in Part III. This analysis also applies to the short-term time-horizon objection. Under basic principles of valuation, short-term and long-term investors both have incentives to maximize long-term value, and the market price subsumes all time horizons-short, intermediate, and long. See Black \& Kraakman, supra note 49, at 532-33 (asserting that "even short-term investors have an incentive to maximize the firm's long-term value, because only by doing so can they maximize the price at which long-term investors will buy the shares that the shortterm investors will soon want to sell"). If the market price does so accurately, then there should be no perverse effects. 
eliding two critical points. The first of these is taken up in Part II. There we show that in the years since the takeover era, the legal model has proven highly responsive to shareholder interests and demands, ameliorating agency costs. The second point is addressed in Part III. The shareholders, even as they plausibly expect that an agency model would further reduce agency costs, fail to confront new costs that would result from the change, in particular suboptimal results stemming from managing to the market. In our view, once these countervailing points are on the table, the shareholder empowerment case falls well short of surmounting the burden of proof that ordinarily confronts proposals for fundamental structural change.

\section{SYSTEMIC RESPONSIVENESS}

We have seen that the shareholder proponents' win-win scenario predicts that shareholder empowerment will cause agency costs to decline and capital to flow to the best use, and that agency costs will persist absent shareholder empowerment. Agency-cost reduction and shareholder empowerment move in lockstep in this picture-you do not get one without the other. This sine qua non posits constant, highly salient agency costs and claims that fundamental law reform is the only way to reduce them. This in turn implies that the corporate governance system leaves big money on the table in the ordinary course, a proposition that to us is counterintuitive.

This Part challenges the shareholder sine qua non. Our challenge follows from the lesson Jensen and Meckling taught in their classic work on agency costs: institutions change in response to market incentives. In Jensen and Meckling's framework, managers and shareholders address agency costs as they arise over time, in the managers' case by bonding their fidelity and in the shareholders' case by monitoring their investments. ${ }^{78}$ To the extent agency costs remain unaddressed, it is because they are too costly for the parties to remove themselves. $^{79}$ Agency-cost reduction, then, is as much an endogenous incident of the system's operation as are agency costs themselves. A prediction results for corporate governance: as new agency costs ap-

Thus, the shareholder proponents rely entirely on the robustness of the market price of the stock as a predictor of fundamental value.

${ }^{78}$ See Michael C. Jensen \& William H. Meckling, Theory of the Firm: Managerial Behavior, Agency Costs and Ownership Structure, 3 J. FIN. ECON. 305, 308 (1976).

${ }^{79}$ See id. (explaining how many agency costs can be avoided through principal monitoring and agent bonding expenditures, and referring to the remaining agency costs as the "residual loss"). 
pear, we can expect the system to find ways to reduce them, even as a residual component of agency costs will persist in the wake of the system's adjustments.

The shareholder sine qua non, in contrast, follows from a static picture of agency costs and corporate governance institutions. This holds that managers will systematically fail to maximize value in predictable ways. They will favor conservative, low-leverage capital structures, misinvest excess cash in suboptimal projects, fail to reduce excess operating costs, and resist premium sales of control. All of these missed opportunities amount to agency costs that could be reduced if the law provided for greater shareholder input.

This fixed picture of systemic shortcomings derives less from economic theory than from a particular time and governance context. The time was the 1980s, and the context was the debate over hostile takeovers. At the time, the management predilection for institutional stability had significant negative implications for productivity, with an open playing field for hostile bids as the agency-cost corrective of choice. ${ }^{80}$ This Part uses Jensen and Meckling's framework as a lens for reviewing subsequent history, contending that the corporate governance system has been dynamic rather than static in addressing agency costs. Indeed, developments on the front lines of business practice have led to a series of agency-cost-reductive changes. We use four critical examples to indicate that recent history bears out the JensenMeckling prediction of responsive agency-cost reduction both by actors inside corporations and actors in the financial markets. First, managers emerged from the 1980s sensitized to the benefits of shareholder-value maximization even as the board of directors emerged as a more robust monitoring institution. Hostile takeovers lost their place at the cutting edge of corporate governance as a result. Second, the revival of private equity buyouts showed that disciplinary merger activity can proliferate even in the absence of either actual or threatened hostile bids. Third, the appearance of hedge fund activists showed, much to the surprise of many, that the prevailing legal model of the shareholder franchise can be well suited to shareholder intervention. Finally, a shareholder-directed break in a longstanding pattern of corporate cash payouts accompanied the hedge funds' appearance.

${ }^{80}$ See, e.g., Reinier Kraakman, Taking Discounts Seriously: The Implications of "Discounted" Share Prices as an Acquisition Motive, 88 COLUM. L. REV. 891, 897-901 (1988) (offering two hypotheses on the sources of discounted share prices). 
Cumulated, these developments show that the governance system works dynamically within the prevailing legal model to remove money on the table stemming from excess agency costs. Shareholder empowerment proponents have played an important role in this process by exerting continuing pressure on directors and managers. They are deservedly applauded for their efforts (as are directors and managers who weigh in against them in the public debate). Even so, a question arises as to the need for greater shareholder empowerment.

\section{A. Corporate Governance and the Market for Corporate Control}

We start with an evolutionary account of the corporate governance system put forward by Bengt Holmstrom and Steven Kaplan in 2001. They surveyed the evolution of shareholder-manager relations, noting that a regime of market-oriented corporate governance emerged in the wake of the 1980s. They depicted the takeover wars as a reaction to an external shock caused by economic factors such as deregulation, globalization, and new information and communications technologies. The financial markets, they observed, showed a comparative advantage over management in undertaking the structural adjustments made necessary by the changes. ${ }^{81}$ Viewed from this perspective, the shift to market control followed neither from its intrinsic superiority respecting capital allocation nor from a structurally embedded level of excess agency costs but from transitory economic factors. ${ }^{82}$ A different economic environment, said Holmstrom and Kaplan, could trigger a shift away from the markets. ${ }^{83}$

${ }^{81}$ Holmstrom \& Kaplan, supra note 41, at 122-23.

${ }^{82}$ See id. at 137 (suggesting that "markets have come to play a bigger role not because they have become better at allocating capital and not because managers misbehaved, but rather because the market's comparative advantage has been favored by economy-wide trends in deregulation, globalization, and information technologies").

${ }^{83}$ In discussing potential future developments, Holmstrom and Kaplan stated,

We have argued that at least some of the efficiency gains associated with these changes can be traced to the comparative advantage of markets in undertaking large-scale change. Since these effects are temporary, it is possible that the current level of market influence on the governance and organization of firms is going to abate. It is not hard to build a scenario in which the pursuit of shareholder value becomes a less important guideline to managers in the next few years. . . If the stock markets are flat or down for the next few years, then the extensive reliance on stock options may again dissipate, leading managers to have less focus on stock prices.

Id. at 140 . 
For Holmstrom and Kaplan, the takeover shock in turn caused a governance response: shareholder-oriented economic assumptions took hold within corporate boardrooms. Incentive realignment was essential in bringing this about, and the move to equity-based management compensation duly encouraged managers to see things the shareholders' way. Thus, restructuring found its way into strategic business planning in the ordinary course. Corporate governance practices changed, too, with the emergence of the independent monitoring board. By all available indicators, the move to board independence and more vigorous monitoring continues unabated. ${ }^{84}$

Significantly, none of this required any changes in the prevailing legal model. The emergence of the independent board did occasion some pushing and shoving in the private sector, manifested in the gestation of the American Law Institute Corporate Governance Project. ${ }^{85}$ But it can still be fairly described as a joint effort by directors and investors seeking best corporate practices. Regulatory mandates came after the fact. ${ }^{86}$ The system, in sum, became more cognizant of the need to reduce agency costs, with private ordering as the means to the end. ${ }^{87}$

Hostile takeovers decreased in policy salience as the market context changed. Merger volume reached new records, and the transactions were overwhelmingly friendly. ${ }^{88}$ Managers proved willing to sell.

${ }^{84}$ See Marcel Kahan \& Edward Rock, Embattled CEOs 37-46 (Eur. Corp. Governance Inst., Law Working Paper No. 116/2008, 2008), available at http://ssrn.com/abstract= 1281516 (surveying the range of pertinent empirical measures of changes in boards of directors). We make the same assertion respecting section $162(\mathrm{~m})$ of the Internal Revenue Code, enacted in 1994, which limits the corporate tax deductability of salaries to $\$ 1$ million. I.R.C. $\S 162(\mathrm{~m})$ (2006). Had the governance system not changed its views first, we doubt it would have occurred to Congress to add the section.

${ }^{85}$ See Jonathan R. Macey, The Transformation of the American Law Institute, 61 GEO. WASH. L. REV. 1212, 1218 (1993) (describing conflicting views between the American Law Institute and corporate management).

${ }^{86}$ The stock exchange rules mandating committees arrived only after Enron. These, for the first time, hard-wire the majority-independent board of directors. N.Y. STOCK EXCH., LISTED COMPANY MANUAL § 303A.01 (2009), available at http:// nysemanual.nyse.com/LCM/Sections (follow "Section 3" hyperlink). Not only is an independent director majority now mandated, but independence is formally defined. Id. §303A.02. Accompanying mandates include separate meetings for outside directors and for all independent nominating, compensation, and audit committees. Id. $\S \S 303 \mathrm{~A} .03-06$.

${ }^{87}$ Thus did Hansmann and Kraakman declare an end to corporate law history at the new century's start. See Hansmann \& Kraakman, supra note 19, at 439 ("There is no longer any serious competitor to the view that corporate law should principally strive to increase long-term shareholder value.").

88 See Kahan \& Rock, supra note 59, at 878-80, 879 tbl.2 (detailing trends in M\&A activity from 1988 to 2000 ). 
Stock options and exit compensation provided a carrot, and majorityindependent boards held out a stick in the form of a rising rate of CEO dismissals. ${ }^{89}$ Hostility became less a fundamental transactional distinction and more a secondary strategy choice determined by costbenefit calculations at the acquiring firm. ${ }^{90}$ The hostile offer's diminishing importance is further confirmed by the diminishing incidence of defensive devices in corporate contracts. Staggered boards (which together with poison pills afford the maximum available protection) among S\&P 100 companies declined from $44 \%$ to $16 \%$ between 2003 and 2008; the decline among S\&P 500 companies was from $57 \%$ in 2003 to $36 \%$ in 2007 . $^{91}$

Meanwhile, the private equity buyout is the segment of the mergers and acquisitions market most likely to entail the post-closing governance discipline sought by the shareholder camp, a segment that experienced a remarkable revival beginning in the mid-1990s. Buyout firms act as aggressive blockholders, closely monitoring management performance and imposing performance targets. ${ }^{92}$ The private equity business model includes and depends on an active threat of manager removal even as it includes and depends on the participation of management incumbents and incentivizes them with a share of the equity. Leverage enhances the threat by interpolating the possibility of downside disaster and magnifying the financial payoff for success. ${ }^{99}$ Discipline, accordingly, is wrought into these companies' governance structures. Pre-closing hostility, however, is avoided. When the recent buyout boom peaked in 2006, buyouts comprised forty-two percent of total merger activity as measured by number of transactions. ${ }^{94}$

All of this shows the corporate governance system acting out the Jensen and Meckling model. Managers bonded themselves by playing

${ }^{89}$ See id. at 881-84 (describing the effects of having independent board members).

${ }^{90}$ See G. William Schwert, Hostility in Takeovers: In the Eyes of the Beholder?, $55 \mathrm{~J}$. Fin. 2599, $2600(2000)$ (suggesting that "the distinction between hostile and friendly offers is largely a reflection of negotiation strategy").

${ }_{91}$ Kahan \& Rock, supra note 84, at 21-22. The trend of decline is also evident in smaller firms, but the magnitude is less-in $2007,58 \%$ of S\&P 400 mid-cap firms and $55 \%$ of S\&P 600 small-cap firms had staggered boards. Id. at 22.

${ }^{92}$ See Brian Cheffins \& John Armour, The Eclipse of Private Equity 9 (Eur. Corp. Governance Inst., Law Working Paper No. 082/2007, 2007), available at http:// ssrn.com/abstract=982114 (noting that "management will be forced to adhere to strict, results-oriented financial projections").

${ }^{93}$ See id. (observing that " $[\mathrm{t}]$ he overall result is a more dynamic and challenging boardroom style than prevails in public companies").

${ }^{94}$ William W. Bratton, Private Equity's Three Lessons for Agency Theory, 9 EUR. Bus. ORG. L. REV. 509, 513 fig.1 (2008). 
ball with the independent board, aligning their personal wealth with that of the shareholders and, in a growing number of cases, giving up their takeover defenses. Investors simultaneously stepped up their monitoring. Agency-cost reduction was the end in view on both sides. The market power that first registered in the conflicts of the 1980s continued to register, ${ }^{95}$ but in a more cooperative framework. Shareholder value creation became embedded in corporate practice under the prevailing legal model. No fundamental, facilitative legal change was needed. ${ }^{96}$

A shareholder proponent might counter these observations by noting that legally sanctioned antitakeover measures increase the costs of takeovers and thereby diminish the intensity of market discipline and lead to increased agency costs. That point certainly carries for some firms at some times. ${ }^{97}$ But the Jensen and Meckling model antic-

${ }^{95}$ See Bengt Holmstrom \& Steven N. Kaplan, The State of U.S. Corporate Governance. What's Right and What's Wrong? 7-8 (Eur. Corp. Governance Inst., Finance Working Paper No. 23/2003, 2003), available at http://ssrn.com/abstract=441100 (“[T]he accomplishments of the 1980 s were by no means forgotten. By the 1990s U.S. managers, boards, and institutional shareholders had seen what LBOs and other market-driven restructurings could do.").

${ }^{96}$ See Kahan \& Rock, supra note 59, at 897-99 (observing that "the use of adaptive devices seems to work reasonably well").

${ }^{97}$ We note, however, that empirical results on the economic effects of takeover defenses across the board are mixed. The literature on takeover defenses provides a good example of the empirical back-and-forth. Many assert that takeover vulnerability influences stock prices even today. Gompers, Ishii, and Metrick compared portfolios made up of firms with "strong" and "weak" shareholder protections (with "weak" including antitakeover protection) and showed that, between 1990 and 1998, a long position in strong-protection firms and a short position in weak-protection firms would have earned an annual abnormal return of $8.5 \%$. Paul Gompers, Joy Ishii \& Andrew Metrick, Corporate Governance and Equity Prices, 118 Q.J. ECON. 107, 144 (2003). Bebchuk and Cohen conducted a subsequent test focused on the staggered board, which, together with the ubiquitous poison pill, makes for a state-of-the-art defensive barrier. They show a statistically significant reduction in firm value at the $99 \%$ confidence level. Lucian A. Bebchuk \& Alma Cohen, The Costs of Entrenched Boards, 78 J. FIN. EcON. 409, 421 (2005). They also test for economic significance, finding that a staggered board lowers Tobin's $Q$ by 17 points. Id. at 424 . A number of complementary studies show connections between antitakeover provisions and specific undesirable results-bad mergers, higher wages, and low management turnover. See Kenneth A. Borokhovich, Kelly R. Brunarski \& Robert Parrino, CEO Contracting and Antitakeover Amendments, $52 \mathrm{~J}$. FIN. 1495, 1496 (1997) (correlating antitakeover adoption and higher levels of compensation); Ronald W. Masulis, Cong Wang \& Fei Xie, Comporate Governance and Acquirer Retums, 62 J. FIN. 1851, 1883 (2007) (studying 3333 acquisitions from 1990 to 2003 and showing lower abnormal bidder returns for firms with antitakeover provisions, controlling for product market competition, equity-based pay, institutional ownership, and board characteristics); Wayne H. Mikkelson \& M. Megan Partch, The Decline of Takeovers and Disciplinary Managerial Turnover, 44 J. FIN. ECON. 205, 206 (1997) (comparing management turnover in two periods, 1984-1988 and 1989-1993). 
ipates these costs, too, with its residuum of irreducible agency costs. Given all of the adjustments described above, it is hard to project a revival for the hostile takeover, quite apart from the costs incident to antitakeover regulation.

\section{B. New Blockholders}

Shareholders who own large blocks of stock suffer no lack of empowerment, whether they own controlling blocks or noncontrolling blocks of sufficient size to assure board representation and inside influence. Shareholder proponents have long bemoaned the relative absence of these blockholders in U.S. equity capital structures, specu- lating that they might, if we had them, make up the disciplinary deficit under the prevailing legal model. They once looked to blockholding arrangements in corporate governance systems in other countries to

None of this is conclusive. Endogeneity problems prevent the studies from proving conclusively that antitakeover provisions cause lower stock prices. Gompers, Ishii, and Metrick's abnormal positive returns could represent unanticipated benefits of good governance or may reflect environmental changes unrelated to governance. See Marco Becht, Patrick Bolton \& Ailsa Röell, Comporate Governance and Control 43 (Eur. Corp. Governance Inst., Finance Working Paper No. 02/2002, 2005), available at http://ssrn.com/abstract=343461 (warning of the limitations of Gompers, Ishii, and Metrick's findings). In addition, the market may take antitakeover provisions as a signal of poor management quality or a lack of shareholder orientation. See John C. Coates IV, Takeover Defenses in the Shadow of the Pill: A Critique of the Scientific Evidence, 79 TEX. L. REV. 271, 301-02 (2000) (acknowledging that market reaction to antitakeover measures will depend on investors' prior beliefs about management and shareholder orientation). Other unobservable variables may be in play. Market actors may simply overestimate the salience of the takeover threat. Chief executives may do the same thing. Finally, a study of the performance of the Gompers, Ishii, and Metrick portfolio after 2003 reverses the performance result, suggesting that the original result was sensitive to the distinct performance patterns of technology firms during the study period. John E. Core, Wayne R. Guay \& Tjomme O. Rusticus, Does Weak Governance Cause Weak Stock Returns? An Examination of Firm Operating Performance and Investors' Expectations, $61 \mathrm{~J}$. FIN. 655, 681-84 (2006) (showing that the poor-governance-performance portfolio outperformed the good-governance-performance portfolio during 2000-2003, and finding no evidence of a causal relationship between governance and operating performance).

It should also be noted that other studies of takeover defenses reach the opposite conclusion. One study of the subsequent performance of firms adopting takeover defenses finds no performance decline. See Mark S. Johnson \& Ramesh P. Rao, The Impact of Antitakeover Amendments on Corporate Financial Performance, 32 FIN. REV. 659, 660, 669 (1997) (surveying a range of financial measures with respect to more than 600 antitakeover amendments adopted between 1979 and 1985 and finding no adverse effect). Later performance improvement has even been detected. See Laura Casares Field \& Jonathan M. Karpoff, Takeover Defenses of IPO Firms, 57 J. FIN. 1857, 1883 (2002) (comparing initial public offering (IPO) firms with and without takeover defenses and finding that defenseless firms underperform for the first two years but that there are no significant performance differences thereafter). 
see if conditions favorable to blockholding could be replicated here, but without success. ${ }^{98}$ Yet, in recent years, after all hope seemed lost, homegrown blockholders did appear, but not in the form predicted.

Activist hedge funds broke the mold. They take significant equity stakes in target companies-generally five to fifteen percent of the target's stock is the range. They mount hostile challenges to managers and business plans at publicly traded firms worldwide. They are impatient shareholders, who look for value and want it realized in the near or intermediate term. They tell managers how to realize the value and challenge publicly those who resist the advice, using the proxy contest as a threat. The strategy proved successful during the bull market run up to $2008 .^{99}$ The leading empirical study looks at the period 2001 to 2006 and pairs 236 activist hedge funds with 1059 publicly traded targets. ${ }^{100}$ These activist engagements persist, albeit in diminished numbers since the financial collapse. ${ }^{101}$ Whether the number of targets rises or falls in the future is unclear, because an upward

98 See Mark J. RoE, Strong Managers, Weak OWners: THE Political RoOts of AMERICAN CORPORATE FINANCE 223-24 (1994) (discussing how U.S. concentration trends slowed in the early 1980 s and how, in the 1990s, they were only moving slightly toward the large blocks present in Japan and Germany); Ronald J. Gilson \& Reinier Kraakman, Investment Companies as Guardian Shareholders: The Place of the MSIC in the Corporate Governance Debate, 45 STAN. L. REV. 985, 1006-09 (1993) (mentioning several empirical studies that show a "mildly positive relationship between active large-block shareholders and corporate performance"). It turned out that the incentives that supported blockholding abroad could not be replicated domestically. Path dependencies within the system retarded its adaptability. At the same time, blockholding in other countries followed from their different political environments, particularly their stronger social democratic systems. See Lucian Arye Bebchuk \& Mark J. Roe, A Theory of Path Dependence in Comporate Ownership and Governance, 52 STAN. L. REV. 127, 169 (1999) (positing that path dependence causes advanced economies to differ in their ownership structure, despite pressures to converge); Mark J. Roe, Chaos and Evolution in Law and Economics, 109 HARV. L. REV. 641, 644-46 (1996) (describing how both path dependence and chaos theory account for variations in institutions, within a range of acceptable economic efficiency).

${ }^{99}$ See, e.g., Alon Brav et al., Hedge Fund Activism, Corporate Governance, and Firm Performance, 63 J. FIN. 1729, 1739-45 (2008) (listing and discussing five motives for hedge fund activism and describing two examples of activist events).

${ }^{100} I d$. at 1739.

${ }^{101}$ See, e.g., Josh Hyatt, Getting Smaller, But Not Quieter, CFO, Feb. 2009, at 17 (discussing how, despite decreasing hedge fund assets, the hedge fund industry still appeals to risk-taking activist investors looking for undervalued companies); Ken Squire, A Golden Age for Activist Investing, BARRON'S, Feb. 16, 2009, at 30 (describing the perfect situation for activist shareholders: enthusiasm for shareholder rights and distressed equity markets); Gregory Zuckerman, Activists Must Adjust Their Aim, WALL ST. J., Apr. 27, 2009, at C10 (noting that while the flow of new activist engagements continues, funds have lost value in lockstep with market averages, leading to investor withdrawals). 
stock market and ready credit together played an important role in facilitating the phenomenon.

The activist funds have drawn heavily on the financial agenda in the shareholders' agency-cost playbook. ${ }^{102}$ There are four main means to the end of agency-cost reduction and value creation: increasing leverage, returning excess cash to shareholders, realizing premiums through the sale of going-concern assets, and cutting operating costs. The activists for the most part drew on the first three plays, using their newly discovered power to prompt borrowing, force the disgorgement of large cash accounts and the sale of operating divisions, and, in some cases, force the sale of the target company itself. ${ }^{103}$ In contrast, the record on cost-cutting initiatives, which tend to require expertise and knowledge respecting internal operations, is sketchier. ${ }^{104}$

Meanwhile, the activists' record of success further testifies to the capital markets' ability to adapt within the prevailing legal framework. The strategy, while hostile, only rarely looks to the market for corporate control. ${ }^{105}$ Instead, the players act out a game of threat and resistance, in which victory lies in either the target's diffusion of the threat with a governance concession or, in the larger number of cases, with the insurgent's entry to the boardroom as a minority blockholder. Payoff through board membership means taking the benefit of the richer informational base available inside the company and, in many cases, movement toward a cooperative outcome. ${ }^{106}$

Significantly, the appearance of these new blockholders can be explained by reference to the alignment of incentives bound up in their shareholding. Hedge funds are independent actors, where other institutional investors are not. They do not sell services to the class of companies they target and so, unlike conventional mutual fund advisors, are unconflicted. $^{107}$ They lock up investor money for longer periods than do mutual funds and thus have time horizons better suited to gover-

${ }^{102}$ See supra text accompanying note 80.

${ }^{103}$ See William W. Bratton, Hedge Funds and Governance Targets, 95 GEO. L.J. 1375, 1390-1401 (2007) (listing and describing four ways in which an activist investor with influence can get an immediate return on investment: get the target to sell itself, get the target to sell a major asset, get the target to pay out spare cash, or have the target change its long-term business plans).

Id. at 1413-15.

${ }^{105} I d$. at $1426-27$.

${ }^{106} I d$. at 1428 . At the same time, activist hedge funds rely on trading-market liquidity to facilitate exit at a time of their own choosing. Id. at 1412-13.

${ }^{107} I d$. at 1384 . 
nance activism. ${ }^{108}$ Finally, the funds in question concentrate on fundamental analysis ${ }^{109}$ and so pick their targets on a fuller informational basis than customarily is the case with institutional equity investors.

It follows that the barriers to shareholder intervention embedded in the prevailing legal model are less salient than previously assumed. The problem lies less with the legal model and more with incentive constraints bound up in institutional shareholding. The landscape, however, is dynamic. The hedge funds have inspired interventions by large, mainstream investment advisors; they also have depended on and received the support of other, more passive institutional investors. ${ }^{110}$ The emerging picture bespeaks the robustness of a system that channels shareholder inputs through the board-election franchise.

The point is not that hedge fund activism by itself reduces agency costs to zero. ${ }^{111}$ Indeed, activist shareholder intervention, whether from a hedge fund blockholder or in the course of a private equity buyout, confirms the continued presence of the agency costs that shareholder proponents seek to control. ${ }^{12}$ The point instead is that, given agency costs and the right incentive alignment, the system will

$108 I d$.

109 Id. at 1383 .

${ }^{110}$ See Kahan \& Rock, supra note 84, at 14-17 (discussing changes in mutual funds, such as more activist behavior, which is usually expected from hedge funds, and cooperation with hedge funds designed to pressure a target's management).

111 Private equity, which carries blockholding to its logical conclusion, presents a telling comparison case. It has had a mesmerizing effect on some agency theorists, who have proposed ownership by private equity funds as a strong-form solution to the problem of separated ownership and control. See Ronald J. Gilson \& Charles K. Whitehead, Deconstructing Equity: Public Ownership, Agency Costs, and Complete Capital Markets, 108 COLUM. L. REV. 231, 231-32 (2008) (theorizing that private owners can transfer risk in discrete slices to parties who can manage or diversify away those risks, which serves as a lower-cost substitute for traditional risk capital); Michael C. Jensen, Eclipse of the Public Comporation, HARV. BUS. REV., Sept.-Oct. 1989, at 61 (encouraging private equity ownership as a solution to "the conflict between owners and managers over the control and use of corporate resources").

${ }^{112}$ It also should be noted that agency costs at target companies do not by themselves necessarily trigger the requisite financial incentives for outside intervention. Buyouts thrive on cheap, available credit and occur cyclically with its availability. Bratton, supra note 94, at 521-23. Unsurprisingly, "[p]rivate equity volume plummeted 69 percent in 2008 because of the lack of credit." Lindsay Fortado, Linklaters Tops Deal Advisers as ME'A Volume Plummets 38 Percent, BLOOMBERG, Jan. 2, 2009, available at http://www. bloomberg.com/apps/news?pid=20601 109\&sid=aNZBdBiog9_0\&refer=home. Since then, many deals have been restructured, with equity swapped for debt. See Jason Kelly \& Jonathan Keehner, Private Equity Indigestion Comes with Bain Bloomin' Onion Debts, BLOOMBERG, Mar. 11, 2009, available at http://www.bloomberg.com/apps/news?pid= 20601109\&:sid=apUN4GkGPA.1\&refer=home (discussing firms' employment of tools such as debt exchanges and equity infusions to restructure and save deals). 
address them aggressively, just as Jensen and Meckling predicted. With managers, the critical incentive change involved incentive compensation. With shareholders, the incentive barrier stemmed from the shareholders' own institutional frameworks. Once a framework conducive to governance intervention finally appeared, the capital markets provided ready support and the prevailing legal model proved facilitative.

\section{Cash Payouts}

Cash disgorgement is a leading shareholder agenda item. According to an account that Michael Jensen articulated in the 1980s, managers habitually hold onto their spare cash, tending to reinvest it in suboptimal projects. ${ }^{113}$ Suboptimal reinvestment, together with conglomerate bust up, was widely held to be the motivation for 1980s takeovers. It remains at the top of the shareholder financial agenda, even as empirical studies of the problem of suboptimal reinvestment of cash flow have produced mixed results. ${ }^{114}$

Whether or not cash retention remains a serious governance problem, the cash-disgorgement agenda registered in boardrooms with unprecedented success during the later stages of the most recent bull market. Figure 1 below tracks shareholder payouts in the form of dividends and stock repurchases by the companies in the S\&P 500 from 1987 to 2007 . The year 1987 is taken as the start date because it marks the beginning of a three-decade trend of increased resort to open-market repurchases by public companies. ${ }^{115}$ The 1987 year-end S\&P 500 average (247), the companies' total annual dividend payments in 1987 ( $\$ 44.3$ billion) and their 1987 total repurchases ( $\$ 32.5$ billion) are pegged at 100 on the vertical axis. Figure 1 shows relative

${ }^{113}$ Michael C. Jensen, Agency Costs of Free Cash Flow, Corporate Finance, and Takeovers, 76 AM. ECON. REV. 323, 323 (1986).

${ }^{114}$ Compare Henri Servaes, Do Takeover Targets Overinvest?, 7 REV. FIN. STud. 253, 254 (1994) (looking at over 700 takeover targets during the period of 1972 to 1987 and finding overinvestment only in the larger firms in the sample and in the oil and gas industry), with Sheridan Titman et al., Capital Investments and Stock Returns 13 (Nat'l Bureau of Econ. Research, Working Paper No. 9951, 2003), available at http:// www.nber.org/papers/w9951 (showing a negative connection between high levels of investment and stock returns).

${ }^{115}$ The crash of 1987 amounted to an external shock that moved payout policy in the direction of repurchases. See William W. Bratton, The New Dividend Puzzle, 93 GEO. L.J. 845, 871 (2005) ("[The] OMR [(open market repurchase)] advantage was first discovered in the wake of the stock market crash of 1987. The crash brought an unprecedented increase in OMR programs ...."). 
increases and decreases to 2008 , when the S\&P 500 closed at 366 , total dividends were $\$ 247$ billion, and total repurchases were $\$ 340$ billion. A break in two longstanding trends occurred in 2004. Prior thereto, increases in levels of dividends and levels of repurchases roughly tracked increases in stock prices (with both tending to lag behind the market). There was also a trend of rough parity between total dividends and total repurchases. Both trends ended in 2003 in favor of an increase in net amounts paid out, with the lion's share of the increase in the form of repurchases. In 1987, repurchases amounted to $1.6 \%$ of average market capitalization, and total payout amounted to $3.8 \%$; in 2007, repurchases amounted to $4.6 \%$, and total payout amounted to $6.3 \%$. The dollar amount of annual repurchases increased eighteen-fold from 1987 to the peak year of $2007 .{ }^{116}$

Clearly, managers had become more attuned to the shareholder agenda. ${ }^{117}$ Whether hedge fund activism played a role is a matter of speculation, but the suggestion arises. ${ }^{118}$ The suggestion in the end leads us back to the Jensen and Meckling model. Given excess cash available for distribution, market-based demands for distribution will follow in the ordinary course. ${ }^{119}$ The notable increase in overall levels paid out suggests an additional point: once the market input registers, many managers can be expected to respond voluntarily.

${ }^{116}$ The pattern changed in other respects as well. Prior to 2004, numbers of outstanding shares tended to remain constant even as repurchase activity increased, with new issues of shares incident to merger activity and employee stock option exercises matching or exceeding numbers repurchased. From 2004 to 2007 , in contrast, $65.1 \%$ of S\&P 500 repurchasers reduced numbers of shares outstanding. STANDARD \& POOR'S, S\&P 500 BUYBACKS: THREE YEARS AND \$1.3 TRILLION LATER 6 (2007), available at http:// www2.standardandpoors.com/spf/pdf/index/121307_SP500_THREE_YEARS_OF_BUY BACKS.pdf.

${ }^{117}$ The financial crisis materially chilled buyback activity in 2008 , when "S\&P 500 buybacks reached $\$ 339.6$ billion-a $42.3 \%$ drop from the record setting $\$ 589.1$ billion spent during 2007." Press Release, Standard \& Poor's, S\&P 500 Stock Buybacks Retreat 66\% in Fourth Quarter; Off $42 \%$ in 2008 (Mar. 26, 2009), available at http:// www2.standardandpoors.com/spf/pdf/index/032609_Buyback-PR.pdf?vregion= us\&vlang=en.

${ }_{118}$ A second factor also should be noted. As between dividends and repurchases, managers holding unexercised stock options have a financial incentive to make repurchases. Bratton, supra note 115, at 872-76.

${ }^{119}$ Even as the pattern began to change in 2004 and 2005, Wall Street analysts were complaining that corporations were husbanding cash at historically high levels. See, e.g., Bratton, supra note 103, at 1394 (noting that in 2006 “the S\&P 500's cash accounts stood at the highest point since the early 1980s" and that shareholders maintained the position that free cash flow should be paid out). 
Figure 1: Payouts, 1987-2008

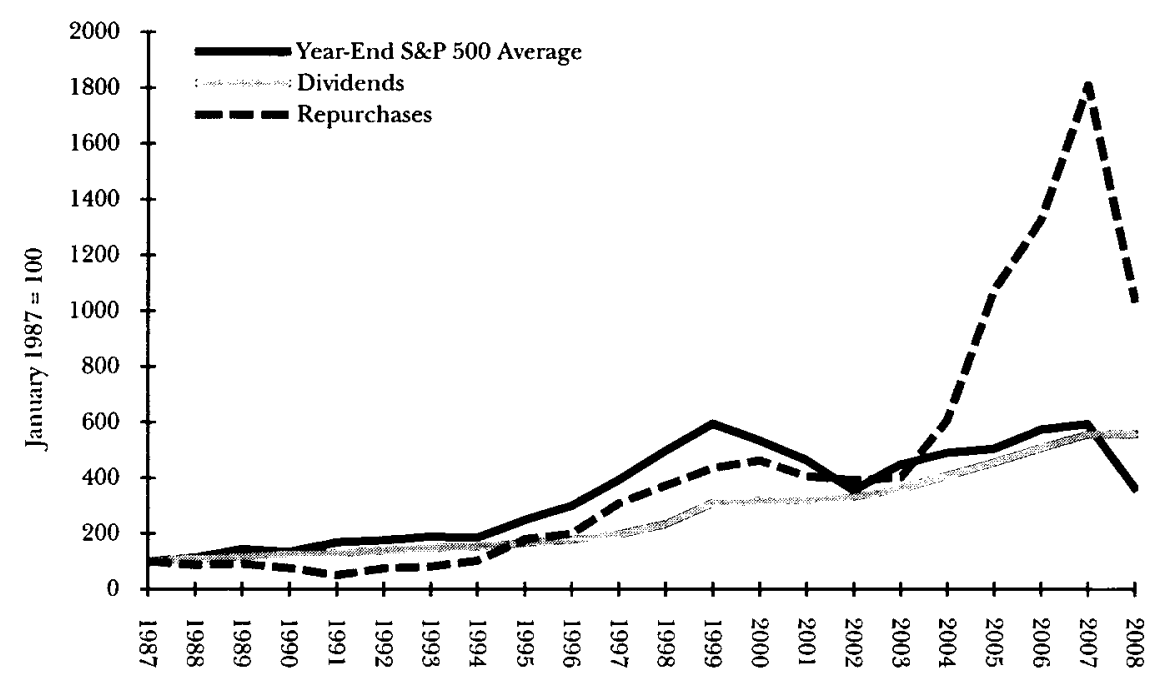

\section{Summary}

This Section's title, "Systemic Responsiveness," summarizes our reading of institutional changes within corporate governance. It is an agency-cost story that starts out at the same place and time as the shareholder story-namely, with the external shocks of the 1980s. The shocks-deregulation, globalization, and new technology-were exogenous to the corporate governance system but stemmed from endogenous adjustments elsewhere in the economy. The shareholder story freezes the frame at the end of the 1980 s conflicts, making its case for law reform by depicting the governance system as static and unresponsive. We move the frame forward in time to show that the corporate governance system made a series of endogenous adjustments addressed to agency-cost control both in the boardroom and in the financial markets. Significantly, none of the changes described required resort to new regulation.

The prevailing legal model emerges as a constant factor in this picture of dynamic change. The constancy follows from the legal model's capaciousness. It sets out a minimal list of mandatesmanagement by the board, annual election by the shareholders, and the managers' duty of loyalty. Within this framework, parties may conduct governance as they deem appropriate. Thus the model can accommodate management domination and shareholder passivity on 
the one hand and shareholder activism and management disempowerment on the other. Particular results follow from incentives, which in turn originate in contracts between the corporation and its managers and contracts between investing entities and their investors.

Our argument puts agency costs, as discussed in policy contexts, back in touch with their theoretical roots. Jensen and Meckling predicted not only dynamic adaptation toward the end of removing money from the table but an agency-cost residuum too costly for removal through private ordering. An important point follows: persistent residual agency costs do not by themselves justify regulatory intervention. The cost-benefit case for reducing residual agency costs by regulation must be made independently, and it may lead to the conclusion that the participants are better off bearing the residual costs. The shareholders emphasize benefits only, ignoring the costs implied by their suggested reforms. Part III confronts these costs.

We close this Part with three caveats respecting normative implications. First, this is a positive account, put forward to.import balance to the factual background in which shareholder reform proposals are evaluated and to denude it of any suggestion of economic urgency. Second, the endogenous changes we describe have contractual origins and so benefit from a normative presumption in their favor. But normative questions are by no means foreclosed. We will ask a few of our own, respecting equity incentive pay, in Parts III and IV. Third, our picture of systemic responsiveness would, if extended to the extreme, imply that law is irrelevant. We would not make this extension. To the contrary, we think that law matters here because it accords the board of directors a zone of discretion in which to make informed business decisions disfavored by the market, a view presented more fully in Part III.

\section{SHAREHOLDER EMPOWERMENT AND ECONOMIC THEORY}

Everybody agrees that managers know more than shareholders. Everybody also agrees that agency costs arise when managers use this informational advantage for their own gain. The result is one of the paradigmatic problems that corporate law tries to solve. Shareholder advocates would address the problem by giving the shareholders sufficient power to impress their preferences, as expressed in market price signals, upon the managers. This gives rise to two key questions: what do the shareholders whose trades shape market prices actually know, and what does the market price teach the wider group of shareholders? Shareholder empowerment assumes that the price setters know 
quite a bit and that the wider group learns a lot from the price the former set, including not only the true value of the corporation but answers to specific questions such as whether or not managers are doing a good enough job to deserve the compensation proposed by the board of directors. In this Part, we appraise these assumptions, addressing the question of what shareholders actually know and taking into account not only the traditional literature on information asymmetries but also the emerging literature on heterogeneous expectations.

We begin on the positive side of the street, stating the best case for shareholder empowerment. This conjoins the semi-strong form of the Efficient Capital Market Hypothesis (ECMH) and the Capital Asset Pricing Model (CAPM) to depict a world in which market prices, although reflecting only information from past market prices and current publicly available information, accurately reflect expectations respecting future fundamental value. We show that the market price, thus modeled, can indeed signal a need to reduce agency costs. But we also highlight a problem of diminishing returns. The market price sends reliable governance signals only in a subset of cases characterized by clear-cut issues and minimal information asymmetries. As governance issues become more complex and information asymmetries more pervasive, market signals become difficult to read.

We then cross to the negative side of the street to confront a critical question: if management's informational superiority presents a paradigmatic problem, how does the stock price surmount the information asymmetry barrier? The answer is that it does not. Strongform efficiency, under which the stock price impounds all private as well as public information, does not hold; hence, managers know more than they disclose and the stock price does not impound the undisclosed information. Traditional ECMH makes a relatively modest claim respecting the informativeness of the market price. Its implications for corporate governance are therefore modest.

Finally, we tread deeper into negative territory to ask what happens when managers shape business policy to cater to uninformed market prices. This inquiry upsets the neatness of even the limited claims that market efficiency holds for corporate governance. New corporate finance models based on heterogeneous expectations make particularly stark projections of suboptimal results. The heterogeneity models show that the information conveyed by the price sometimes can be misleading for purposes of business policymaking. These periods, although limited, are important. 
We go on to explore these models' implications for corporate governance, reaching two critical conclusions: First, shareholder empowerment will make it much more difficult for a good board of directors to resist pressures to manage to the market. This can lead to bad business decisions, either due to information asymmetry or a run of speculative mispricing. Second, incentive-compatible executive compensation and shareholder empowerment are inconsistent goals. If executive compensation can be fixed by requiring longer holding periods, it is then turned around and unfixed if managers are encouraged to manage the market as a response to shareholder empowerment.

We note a methodological constraint. We confine our economic evaluation to the rational-expectations framework held out by traditional financial economics. We think this "high church" literature more than suffices to undercut the case for shareholder empowerment. At the same time, we acknowledge a significant body of behavioral work on market pricing, both theoretical and empirical. ${ }^{120} \mathrm{We}$ omit reference to it for simplicity, toward the end of avoiding an unnecessary excursion onto disputed methodological territory.

Section A shows what market pricing efficiency can and cannot do for the shareholder case. Section B, describing the pricing salience of

${ }^{120}$ These studies focus on sentiment, investment styles, and asset tastes. For a review of the behavioral finance literature, including studies in trading activity, research in corporate finance, and analyses of stock returns, see Avanidhar Subrahmanyam, $B e-$ havioural Finance: A Review and Synthesis, 14 EUR. FIN. MGMT. 12 (2007). Traditional pricing theory holds that the prices of two assets move together as a result of comovement in fundamental value. But, given market frictions, limits to arbitrage, and irrational (or "sentimental") investors, comovement might have other causes. Coordinated demand, then, influences prices. See Malcolm Baker \& Jeffrey Wurgler, Investor Sentiment and the Cross-Section of Stock Retums, 61 J. FIN. 1645, 1648-50 (2006) (examining sentiment's impact on the cross section of stock returns from 1963 to 2001 and showing that high-sentiment investors gravitate to young, small, unprofitable growth stocks or distressed issues, while low-sentiment investors like large, profitable dividend payers, and that abrupt changes in sentiment result in demand shocks for sensitive stocks); Nicholas Barberis et al., Comovement, 75 J. FIN. ECON. 283, 284 (2005) (showing that investors group assets into categories); Nicholas Barberis \& Andrei Shleifer, Style Investing, 68 J. FIN. ECON. 161, 162-64 (2003) (examining the impact of style investing on institutional and individual investors); Paul A. Gompers \& Andrew Metrick, Institutional Investors and Equity Prices, 116 Q.J. ECON. 229, 230-36, 244 (2001) (showing that institutions like large, liquid stocks with relatively low returns in the year prior to purchase, and that institutional demand for large issues accounted for nearly fifty percent of the issues' relative price appreciation of large over small stocks across the period 1980 to 1996); Alok Kumar \& Charles M.C. Lee, Retail Investor Sentiment and Retum Comovements, 61 J. FIN. 2451, 2453-54 (2006) (showing that retail investors tend to nest in small firms, lower-price firms, firms with relatively low levels of institutional ownership, and value firms). 
information asymmetries, shows that the best case is incomplete. Section $\mathrm{C}$ details the impact of heterogeneous investor expectations and the value-destructive effects of managing to a speculative market.

\section{A. Pricing Efficiency and the Case for Shareholder Empowerment}

If financial markets were strong-form efficient, stock prices would fully and correctly reflect all relevant information, both public and private. In such a state of the world, the shareholder proponents' case would be compelling, and the paradigmatic problem of corporate law would vanish. Shareholders could know as much as the managers if they carefully scrutinized the stock price and attended to public disclosures and leaks of material nonpublic information. Powerful implications for corporate governance would obtain.

If shareholders were thus informed, directors might understandably view themselves more as agents of the shareholders and less as their trustees. As faithful agents, the directors would seek to learn their principals' wishes. The financial market would hold out the best source of this information, since the movement of stock prices would reveal the shareholders' well-informed preferences respecting corporate developments. Managers might even vet investment decisions with the market and observe the pricing effect, adopting strategies leading to stock price increases and abandoning those leading to stock price declines.

But this is not the state of the world according to the modern corporate finance literature, a literature with complex and easily misunderstood implications for corporate governance. We explore these below and contend that one thing is clear: shareholder proponents wrongly assume that agency costs can be reduced without countervailing negative effects when directors act more like agents and manage to shareholder preferences signaled in market prices.

\section{ECMH, CAPM, and the Value of a Share}

Markets would be strong-form efficient if they priced in all information-material nonpublic information as well as all public information. It is, however, generally accepted that financial markets are not strong-form efficient. ${ }^{\text {II }}$ In contrast, ECMH's semi-strong form is gener-

121 See, e.g., StePhen A. RoSS ET AL., CORPORATE FINANCE 359 (6th ed. 2002) ("Even the strongest adherents to the efficient-market hypothesis would not be surprised to find that markets are inefficient in the strong form."). 
ally accepted. This, sometimes called "informational efficiency," posits that the capital markets embed all publicly available information into security prices. $^{122}$ It has two implications: first, that no trading strategy based on public information can regularly outperform the market, ${ }^{123}$ and, second, that insiders who possess nonpublic information can outperform the market when trading in their own stock. ${ }^{124}$ The latter point is hardly surprising since it means that insiders, even after making all required disclosures, remain better informed than outsiders. Add this up and an important point emerges for our argument: informational asymmetries exist in tandem with "informational efficiency," with the managers and directors having the informational advantage.

Now for a second key point: the informational efficiency posited by ECMH does not imply that the share price equals the pro rata value of the discounted free cash flows of the corporation. ${ }^{125}$ This is a point that is often misunderstood. To say that no investment strategy can outperform the market does not in itself say anything about the stock price's accuracy in measuring the corporation's fundamental valuethat is, the discounted value of expected future free cash flows. ECMH

122 See Burton G. Malkiel, Efficient Market Hypothesis, in 1 THE NEW PALGRAVE DICTIONARY OF MONEY AND FinANCE 739, 739 (Peter Newman et al. eds., 1992). ECMH asserts that the stock market possesses efficiency attributes in terms of three alternative, progressively more inclusive information sets. See, e.g., id. at 739-41. The first, or weak form, defines market efficiency in terms of past market prices. The market is efficient according to the weak form if investors cannot predict future stock price movements based on an information set containing all past price movements. As noted in the text, the second, or semi-strong form, defines market efficiency in terms of all publicly available information. The third, or strong form, includes nonpublic information as part of the information set. Markets are efficient according to the strong form if stock prices include all nonpublic information as well as public information. Consequently, if the strong form were to hold, an investor who was privy to both private and nonprivate information could not consistently earn abnormally large investment returns.

${ }^{123}$ See id. at 739 (asserting that under the "semi-strong form of EMH . . an analysis of balance sheets, income statements, announcements of dividend changes or stock splits or any other public information about a company... will not yield abnormal economic profits").

${ }^{124}$ See Lisa K. Meulbroek, An Empirical Analysis of Illegal Insider Trading, 47 J. FIN. 1661,1696 (1992) ("The analysis suggests that insider trading increases stock price accuracy by moving stock prices significanty."); see also Dirk Jenter, Market Timing and Management Portfolio Decisions, 60 J. FIN. 1903, 1906 (2005) (showing that managers trade as contrarians and earn excess returns on their trades, but that the excess returns disappear after controlling for size and book-to-market effects).

See JOHN Y. CAMpBEll ET AL., THE EcONOMETRICS OF FINANCIAL MARKETS 24-25 (1997) (discussing reasons why "perfect [stock] efficiency is an unrealistic benchmark that is unlikely to hold in practice"). 
only requires that stock price movements mirror a random walk, ${ }^{126}$ and, as long as stock price movements are random, outguessing the market is not possible. Whether the random walk moves around, away from, or ultimately always stumbles into the correct price is another matter. To evaluate this possibility, we must look to CAPM.

The corporation is a collection of assets and its value is the free cash flow that those assets are expected to generate into the indefinite future. CAPM provides the discount rate needed to state those expected future free cash flows as a present value. ${ }^{127}$ The discount rate reflects the riskiness of the expected flows-the more risky the flows, the higher the discount rate and the lower the present value. CAPM is a theory of risk that boils down to the assertion that a given corporation's discount rate will be proportional to its expected future free cash flows' covariance with the economy's free cash flows.

With these building blocks, we can further investigate the question whether efficient stock prices provide an accurate measure of the fundamental value of the corporation-that is, the discounted value of the firm's expected future free cash flows. All turns on the word "expected" in the concept of "expected free cash flows." Since future results are unknowable, fundamental value turns on expected rather than actual cash flows. Nothing in the theory even remotely suggests that these future expectations will be borne out by the passage of time. Expectations can turn out to be wildly incorrect.

Despite this, the statement that "stock market prices are always correct" remains close to being definitionally true. The syllogism is the following: first, financial markets do capture future expectations more reliably than any other mechanism; second, fundamental value turns on expectations of the future free cash flows. Since the market provides the most reliable estimate of future expectations, it is reasonable to define value in terms of market price.

The market-based definition of value is particularly appealing for corporate law because it follows from the valuations of willing buyers and sellers. A key assumption in this line of reasoning, homogeneity

\footnotetext{
${ }^{126}$ RiChaRD A. BREAley ET AL., PRINCIPLES OF CORPORATE FINANCE 333-41 (8th ed. 2006).

${ }^{127}$ See John Lintner, The Valuation of Risk Assets and the Selection of Risky Investments in Stock Portfolios and Capital Budgets, 47 REV. ECON. \& STAT. 13, 27 (1965) ("The analysis thus justifies viewing market values as riskless-rate present values of certaintyequivalents of random future receipts ...." (italics omitted)); William F. Sharpe, Capital Asset Prices: A Theory of Market Equilibrium Under Conditions of Risk, 19 J. FIN. 425, 43642 (1964) (describing the "consistent relationship between ... expected returns and what might best be called systematic risk").
} 
of expectations, further enhances its appeal. ${ }^{128}$ CAPM assumes that all individuals have access to all of the publicly available information and reach the same expectations about the future. As a result, CAPM assumes that all investors employ the same valuation metrics and share prevailing market expectations. Shareholders, market price setters, and passive proxy voters alike become one. Under this model of value, the shareholders expeditiously can deliver governance instructions through the market price. To see how, imagine that a shareholders' meeting was convened to set a value on the company. Under this unitary model of the shareholder, the resulting value would be the market price; it follows that the meeting need not be called in the first place. More generally, under an agency model of the corporation, the manager-agents should look to the market price for the principal's instructions.

Of course, expectations do differ among investors in the real world. One still might believe that the market price reflects the average shareholder's expectations and so provides a reliable proxy for fundamental value. As we shall see below, however, switching to an assumption of heterogeneous expectations generates results that lead to profoundly different implications for corporate law.

\section{Implications for the Case for Shareholder Empowerment}

Shareholder proponents take the market price, as modeled in traditional financial economics, as the best available projection of a corporation's expected future cash flows. They then hold it out as an essential point of reference in the detection and reduction of management agency costs. They do not deny the existence of information asymmetries but, at least implicitly, assume them to have been minimized by increases in market efficiency and a thick layer of disclosure requirements. ${ }^{129}$

A hostile tender offer for a publicly traded company presents the best case for this approach. Hypothesize an offer at a substantial premium over the market price and incumbent managers who contend that their business plan holds out superior prospects for long-term value enhancement. How should the target's directors respond? With minimal information asymmetries, the answer is clear: the directors should ac-

${ }^{128}$ See Sharpe, supra note 127, at 433-34 (assuming "homogeneity of investor expectations" as a condition for equilibrium in capital markets).

${ }^{129}$ See Gordon, supra note 51, at 1548-63 (describing the increase in the content and scope of mandated disclosures over the last fifty years and suggesting a causal role in the rise of the independent board). 
cept the voice of the shareholders as expressed through the market price, which elevates the bid price over the incumbents' business plan.

The case is easy because information asymmetries do not complicate it. In the shareholder proponents' view, when management holds out its business plan as superior in the teeth of the market's rejection, it inappropriately uses its position of informational superiority as an excuse for what amounts to self-interested entrenchment. In the informationally rich environment of the takeover market, it can be argued that informational asymmetries are at their lowest level. Given this, the shareholders know the value of the corporation substantially as well as the managers do. It follows that the market price is the only metric needed to decide the appropriate outcome and that the legal rule should allow shareholders to decide the contest for control at the tendering stage.

Now consider a more difficult case, which concerns the selection of the terms of an executive compensation scheme. In theory, a given scheme should be geared to the recent performance of the individual executives. This recent data, however, will not be fully available to the public. Even given the full set of data, choices remain respecting the terms of the performance-based compensation scheme. The actor designing the package must exercise judgment, for, in practice, there is no generally accepted template that sets out the terms of an optimal package. $^{130}$ Now imagine a package assembled and submitted to the shareholders pursuant to a "say on pay" mandate. How will the shareholders evaluate the plan? Given all of the above, the vote likely will reflect levels of satisfaction with recent price performance rather than considered views about optimal incentive pay or the full set of performance data, much of which will remain unobservable.

More generally, as information asymmetries become greater in scope, which occurs as business-policy choices become more complex, the stock price becomes less an objective report on a particular value outcome and more an input for interpretation. Policymaking becomes an exercise calling for inside information, experience, and sound business judgment. The tie between inputs garnered from shareholder votes, which in turn reflect overall levels of satisfaction with price performance, and the reduction of particular agency costs becomes much attenuated.

${ }^{130}$ For a presentation of the range of positions taken in the literature, see William W. Bratton, The Academic Toumament over Executive Compensation, 93 CAL. L. REV. 1557, 1562-75 (2005) (reviewing LUCIAN BEBCHUK \& JESSE FRIED, PAY WITHOUT PERFORMANCE: The Unfulfilled PROMiSe of EXeCutive CoMPENSATION (2004)). 
Shareholder proponents do not deny this even as they seek to open doors to shareholder intervention. They avoid the trap of recommending that uninformed shareholders routinely make business decisions by focusing on deterrent effects. ${ }^{131}$ Shareholder intervention emerges as a potential threat that managers will avoid by managing to the market. The proponents' case accordingly turns on an implicit assertion: information asymmetries are small relative to the agency costs at stake, so that managing to the market either brings positive results or does no harm.

We disagree with the assertion. The importance of information asymmetries relative to agency costs is an empirical question to which no one has an answer. The best that can be said for the shareholders is that their agenda's credibility improves to the extent that information asymmetries are minimal. But minimal information deficits cannot safely be assumed. Section III.B, which follows, shows that information asymmetries are real. Section III.B goes on to address the claim that managing to the market can do no harm, showing that managing to an uninformed market price can result in suboptimal business policy. That problem reemerges in more acute form in Section III.C, which discusses speculative overpricing under heterogeneous expectations.

\section{B. The Information Asymmetry Problem}

We have seen that strong-form efficiency would support a nearly unassailable case for shareholder empowerment. But financial markets are not strong-form efficient. Information asymmetries are real. Empirical studies confirm this point beyond doubt, showing that managers who trade in their corporation's shares earn abnormally high returns. ${ }^{132}$

Information asymmetries make it difficult for the market to project accurately the free cash flows that the corporation will produce. The difficulties extend to ascertainment of a capitalization rate, ${ }^{133}$ as well as to the projection of future free cash flows. This Sec-

131 See supra text accompanying note 76.

${ }^{132}$ See Malcolm Baker et al., Behavioral Corporate Finance (asserting that "corporate managers have superior information about their own firm," which "is underscored by the evidence that managers earn abnormally high returns on their own trades"), in 1 HANDBOOK OF CORPORATE FINANCE: EMPIRICAL CORPORATE FINANCE 145, 149 (B. Espen Eckbo ed., 2007).

${ }^{133}$ It bears noting that the informational imbalance impacts both sides of the valuation exercise-the ascertainment of the discount rate as well as the projection of future free cash flows. See Wachter, supra note 44, at 792-93 (discussing the inability of existing models to accurately estimate the discount or market capitalization rates). CAPM provides the most common approach for accessing the risk premium in the dis- 
tion explores the implications of these difficulties for corporate governance. It makes two points. First, information asymmetries are not going to go away. Second, the evidence confirms their status as a salient factor in business policymaking. Systemic change that forced management to the market price would enhance their salience, increasing agency costs. An uninformed market is structurally incapable of sending business policymakers a determinative signal. It follows that, given asymmetric information, market signals need to be interpreted on a continuous basis rather than followed blindly. The job of interpretation is an intrinsic management function.

\section{Persistence}

If information asymmetries would just go away, the case for shareholder empowerment would be straightforward. Yet shareholder proponents do not seek a level informational playing field. There is no call for full disclosure in the form of a requirement that corporations disclose all relevant information, ${ }^{134}$ a requirement presently absent from both the federal securities laws and state corporate law.

Nor should there be. Corporate finance theory holds that full disclosure by the firm is prohibitively costly. ${ }^{135}$ Full (or fuller) disclosure carries costs of reduced incentives, increased regulation, and the proprietary cost that follows from sharing private information with competing firms. It also holds out benefits. Better quality disclosure can reduce the firm's equity cost of capital and enhance the liquidity of its publicly traded securities. In equilibrium, the level of disclosure follows from a trade-off of these costs and benefits, with different firms gravitating to different disclosure levels. ${ }^{136}$ Several mechanisms reduce

count rate. More specifically, it employs an empirically derived single risk factor, beta $(\beta)$, that measures a given stock's contribution to the systematic risk in the market portfolio. Although betas customarily are estimated from market data, the true underlying beta depends on the covariance of the firm's free cash flows with the overall market's free cash flows, factors that may be better known by the managers than the market.

${ }^{134}$ We have seen that this is Fama and Jensen's basic point. See supra text accompanying note 31 .

${ }^{135}$ See S.J. Grossman \& O.D. Hart, Disclosure Laws and Takeover Bids, 35 J. FIN. 323, 323-24 (1980) (illustrating formally that full disclosure presupposes three conditions: (1) that investors know that firms possess the information; (2) that affirmative misrepresentation does not occur; and (3) that disclosure is costless).

${ }^{136}$ See John E. Core, A Review of the Empirical Disclosure Literature: Discussion, $31 \mathrm{~J}$. ACCT. \& ECON. 441, 442-44 (2001) ("This choice involves trading off the reduction in the information asymmetry component of the cost of capital that results from increased disclosure quality against the costs of reduced incentives, litigation costs, and proprietary costs." (citations omitted)). 
the asymmetry without eliminating it-the mandatory disclosure system, the work of financial analysts, and the investigations of large, activist shareholders. ${ }^{197}$ The magnitude of the resulting imbalance varies from firm to firm, becoming more severe as the duration of the firm's investments increases, the firm's business plan focuses on growth, and the firm's size is smaller. ${ }^{138}$

\section{Evidence and Effects}

Information asymmetries figure prominently in leading economic accounts of corporate financial practices. ${ }^{139}$ Simply, managers take

${ }^{137}$ See Jeremy C. Stein, Agency, Information and Corporate Investment (noting that even as governance processes, capital structure, incentive contracts, intermediation, and the mandatory disclosure regime reduce informational distortions, some remain unresolved and relevant in equilibrium), in 1A HANDBOOK OF THE ECONOMICS OF FINANCE 111, 115 (George M. Constantinides et al. eds., 2003).

${ }^{198}$ For example, a long-established business with no growth opportunities confronts a relatively small information asymmetry problem. It, accordingly, will have little incentive to go beyond mandated disclosure items. In contrast, a firm with abundant growth opportunities and a more complicated information set has a more serious information asymmetry problem. Depending on the interplay of costs and benefits, its managers may find it advantageous to make additional voluntary disclosures. See Core, supra note 136, at 443 (examining which firms will find it optimal to make voluntary disclosures); see also Paul M. Healy \& Krishna G. Palepu, Information Asymmetry, Corporate Disclosure, and the Capital Markets: A Review of the Empirical Disclosure Literature, $31 \mathrm{~J}$. ACCT. \& ECON. 405, 420-25 (2001) (examining the motives behind voluntary disclosure). Investor relations also influence these choices-firms with large analyst followings and large populations of institutional investors tend to disclose more. See Healy \& Palepu, supra, at 416-18 (suggesting that management might voluntarily disclose where analysts give favorable ratings); Paul M. Healy et al., Stock Performance and Intermediation Changes Surrounding Sustained Increases in Disclosure, 16 CONTEMP. ACCT. RES. 485, 48990 (1999) (noting that a multivariate analysis demonstrated that "increased disclosure is related to ... growth in institutional ownership and analyst coverage"). Finally, as the shareholder proponents assert, agency costs also play into the mix. Managers have incentives to make self-serving disclosures. See Healy \& Palepu, supra, at 421, 425 (explaining that managers have incentives to make capital-cost-lowering disclosures). Ultimately, the credibility of any firm's disclosures (and hence the firm's proximity to the optimal level and quality of disclosure) depends on the effectiveness of its governance. See Core, supra note 136, at 444 ("[I]t is the governance structure that constrains the manager to follow optimal policy."). Empirical literature supports all of the foregoing points. See Christian Leuz \& Peter Wysocki, Economic Consequences of Financial Reporting and Disclosure Regulation: A Review and Suggestions for Future Research 23-38 (Mar. 2008) (unpublished manuscript), available at http://ssrn.com/abstract=1105398.

${ }^{139}$ See, e.g., Hayne E. Leland \& David H. Pyle, Informational Asymmetries, Financial Structure, and Financial Intermediation, 32 J. FIN. 371, 372 (1977) (noting that while an entrepreneur may not be able to directly convey inside information, she may be able to signal that information to potential shareholders based on the fraction of equity that she retains); Merton H. Miller \& Kevin Rock, Dividend Policy Under Asymmetric Information, 40 J. FIN. 1031, 1031 (1985) (arguing that "managers know more than outside in- 
advantage of market overvaluation to tap the equity markets. The pattern shows up both with initial public offerings (IPOs) and equity offerings by seasoned issuers. For example, studies show that IPOs are positively correlated with ex ante indicators of overpricing, such as the industry's market-to-book ratios and stock indexes. ${ }^{140}$ Seasoned issuers keep an eye out for market windows: a survey of corporate CFOs shows that two-thirds look for market overvaluation before issuing equity. ${ }^{141}$ Studies also show that IPO issuers underperform relative to comparables for years after the offering, ${ }^{142}$ with the underperformance serving as ex post confirmation of overpricing at the time of the offering. The same result occurs in the years after seasoned issuers sell more stock-the range of underperformance relative to the market is twenty to forty percent during the subsequent five years. ${ }^{143}$ Unsurprisingly, the asymmetrically informed markets react negatively to the

vestors about the true state of the firm's current earnings"); Stephen A. Ross, The Determination of Financial Structure: The Incentive-Signalling Approach, 8 BELL J. ECON. 23, 27-31 (1977) (developing a model that establishes a signaling equilibrium based on the assumption that managers have inside information).

${ }^{140}$ See Baker et al., supra note 132, at 159-60 (surveying literature that suggests equity issuance is correlated with overvaluation); Joshua Lerner, Venture Capitalists and the Decision to Go Public, 35 J. FIN. ECON. 293, 293-94, 299 (1994) (finding, in a comparison of the number of IPOs and a biotechnology equity index, that venture capitalists time IPOs and that "IPOs coincide with the peaks in equity valuations"); Tim Loughran et al., Initial Public Offerings: International Insights, 2 PAC.-BASIN FIN. J. 165, 166 (1994) (finding that, in fourteen of the fifteen countries examined, "IPO volume is positively correlated with the inflation-adjusted level of the stock market"); Marco Pagano et al., Why Do Companies Go Public? An Empirical Analysis, 53 J. FiN. 27, 28 (1998) (finding that "the main factor affecting the probability of an IPO is the market-to-book ratio at which firms in the same industry trade").

${ }^{141}$ See Baker et al., supra note 132, at 159 ("Several lines of evidence suggest that overvaluation is a motive for equity issuance. ... [Two-thirds] of CFOs of public corporations ... state that 'the amount by which our stock is undervalued or overvalued was an important or very important consideration' in issuing equity." (citations omitted)).

${ }_{142}$ See Jay R. Ritter, The Long-Run Performance of Initial Public Offerings, 46 J. FiN. 3, 3 (1991) (contending that "in the long-run, initial public offerings appear to be overpriced," and finding that "in the 3 years after going public these firms significantly underperformed a set of comparable firms matched by size and industry"). Several empirical studies have also found that for IPOs declining profitability and investment after the IPOs suggest that the issuances were incidences of market timing. See Pagano et al., supra note 140, at 28-29 ("Our finding that investment and profitability decrease after the IPO points to the [attempt-to-time-the-market] explanation.").

${ }^{149}$ See Baker et al., supra note 132, at 160 ("[O]n average, US equity issues underperform the market somewhere in the ballpark of $20-40 \%$ over five years."); see also Malcolm Baker \& Jeffrey Wurgler, The Equity Share in New Issues and Aggregate Stock Returns, 55 J. FIN. 2219, 2219 (2000) ("When equity prices are too high, existing shareholders benefit by issuing overvalued equity. When equity prices are too low, issuing debt is preferable. Consistent with this timing hypothesis, firms issuing equity have poor subsequent performance."). 
very announcement of a new stock offering. This limits the availability of equity as a financing alternative, particularly when the managers deem their stock to be underpriced or correctly priced. ${ }^{144}$

Perceived undervaluation also drives financing choices, but in the opposite direction. These companies finance with debt rather than equity. ${ }^{145}$ And, instead of selling more stock, they repurchase stock previously issued. Subsequent returns on repurchased stock are positive, running twelve percent above those on comparables over four years. ${ }^{146}$ Significantly, although the announcement of a repurchase program means a small bump for the stock price, the pattern of positive subsequent returns shows that the market does not fully assimilate the signal's informational content. ${ }^{147}$

Information asymmetries also lead to complications for corporate investment policy. The complications arise when managers manage to the market, factoring expected stock price reactions into their decisions. To see the complications, hypothesize a company with a new, long-term investment project. The new project is complicated and so presents the market with a costly and lengthy exercise in valuation. As a result, the new project is likely to be mispriced by the market. ${ }^{148}$ Giv-

${ }^{144}$ Managers who believe their stock to be correctly priced or underpriced will avoid selling new equity, financing with debt or internal cash flow. See Stein, supra note 137, at 118-19 (examining models of debt financing or cash-flow financing). Managers of firms with good potential investments but constraints on these sources of financing must sell new equity or forego the investments. They are forced to time their financing, and hence their investment, to the underinformed market price, with a sacrifice of flexibility. See Malcolm Baker et al., When Does the Market Matter? Stock Prices and the Investment of Equity-Dependent Firms, 118 Q.J. ECON. 969, 986-90 (2003) (showing that investment by firms with financing constraints is sensitive to the market price).

${ }^{145}$ See Armen Hovakimian et al., The Debt-Equity Choice, 36 J. FIN. \& QUANTITATIVE ANALYSIS 1, 3-4 (2001) (determining that "firms with higher current stock prices (relative to their past stock prices, book values, or earnings) are more likely to issue equity rather than debt and repurchase debt rather than equity" and that this finding is "consistent with agency and information asymmetry models where managers are either reluctant to issue equity at low prices or have an incentive to boost their leverage when the stock prices are low"); Paul Marsh, The Choice Between Equity and Debt: An Empirical Study, 37 J. FIN. 121, 133 (1982) (finding that the total amount of U.K companies' equity and debt issues is related to the performance of the stock and bond markets).

${ }^{146}$ See David Ikenberry et al., Market Underreaction to Open Market Share Repurchases, 39 J. FIN. ECON. 181, 184 (1995) ("Beginning in the month following the repurchase announcement, the average buy-and-hold return over the next four years is more than $12 \%$ above that of a control portfolio.").

${ }^{147}$ See id. at 184 ("The most striking finding ... is that the information conveyed by open market share repurchases is largely ignored.").

${ }^{48}$ See Andrei Shleifer \& Robert W. Vishny, Equilibrium Short Horizons of Investors and Firms, 80 AM. ECON. REV. (PAPERS \& PROC.) 148, 148 (1990) ("The time to disappearance of mispricing depends on how fast... investor misperceptions are cor- 
en managers who cater to the stock price, the risk of underpricing may lead management to pass up the opportunity. ${ }^{149}$ The greater the stress on keeping up the stock price, the more likely this suboptimal result.

Given an uninformed market and managers inclined to cater to the price, investment decisions may be keyed to what the market expects-its schematized picture of the company and its strategy and prospects. When a manager sees an opportunity not yet in the market's picture of the company and predicts that the market will react negatively to a shift in emphasis, she must undertake a process of informational mediation. The result is costly delay. ${ }^{150}$ Contrariwise, if the market ex-

rected...."). There are numerous articles providing empirical confirmation of this mispricing. See, e.g., Craig W. Holden \& Leonard L. Lundstrum, Costly Trading, Managerial Myopia and Long-Term Investment 3-4 (Sept. 16, 2005) (unpublished manuscript), available at http://ssm.com/abstract=809507 (showing that firms selected for long-term traded options (and hence a lower cost of trading on long-term information) increased their research and development $(R \& D)$ to sales ratios twenty-three percent to twentyeight percent compared to matching firms not selected for long-term traded options in the two years following selection); see also Jeremy C. Stein, Takeover Threats and Managerial Myopia, 96 J. POL. ECON. 61, 63-67 (1988) (showing formally that, even absent agency costs, managers of a firm threatened by a takeover will sell an underpriced asset).

We note that direct empirical testing of these assertions is difficult. This follows from the nature of the phenomenon predicted-underinvestment tends to be unobservable by the market. See Stein, supra note 137, at 131 (noting that models of investment can be difficult to test because underinvestment occurs in "activities that are not directly observable by the market" (emphasis omitted)). Market-timing studies showing that firms issuing equity have strong operating numbers two years prior to the issuance and weak numbers thereafter provide indirect evidence, with underinvestment prior to the offering as a possible cause of the earnings pattern. See id. at 132 (examining studies where circumstantial evidence of underinvestment results from such an earnings pattern).

${ }^{149}$ See Richard E. Kihlstrom \& Michael L. Wachter, Corporate Policy and the Coherence of Delaware Takeover Law, 152 U. PA. L. REV. 523, 551-56 (2003) (showing formally that managers vulnerable to a hostile offer and having better information about prospective investments will forego unpopular investment opportunities and fail to maximize the value of the corporation); Jeremy C. Stein, Efficient Capital Markets, Inefficient Firms: A Model of Myopic Corporate Behavior, 104 Q.J. ECON. 655, 667 (1989) (modeling suboptimal investment where managers maximize a weighted average of near-term stock prices and long-run value); see also Miller \& Rock, supra note 139, at 1031-33 (presenting a model of shareholder investment and management decisionmaking where asymmetric information leads to suboptimal levels of investment); M.P. Narayanan, Managerial Incentives for Short-Term Results, 40 J. FIN. 1469, 1469-70 (1985) (showing that reputational incentives can lead to underinvestment).

${ }^{150}$ See Philippe Aghion \& Jeremy C. Stein, Growth Versus Margins: Destabilizing Consequences of Giving the Stock Market What It Wants, 63 J. FiN. 1025, 1025 (2008) (creating a model in which managers can devote resources to either increasing sales growth or improving per-unit profit margins and arguing that devoting resources to one end necessarily means sacrificing the other). As modeled, the market puts more weight on growth metrics when it sees a growth firm and more weight on cost-cutting metrics when it sees a business plan focused on profit margins. Id. at 1032-35. Problems arise for a manager who decides, as events unfold in the product market, to move from a 
pects a company to invest in a line of business that the market believes will be highly profitable in the future, the managers will feel pressured to make the market-favored investment even if they understand that it is suboptimal based on their superior, contrarian information. ${ }^{151}$

Excessive concern about stock price effects also leads to earnings management, which can in turn lead to underinvestment. In a world where institutional fund managers benchmark portfolios by reference to quarterly earnings per share (EPS), ${ }^{152}$ sensitivity to stock market reactions implies a focus on quarterly earnings numbers. ${ }^{153}$ Once management prioritizes meeting the market's EPS expectations, investments that enhance long-term value but impair near-term earnings may be delayed or foregone. ${ }^{154}$ Unsurprisingly, the more sensitive

growth posture to present-profit maximization. The manager devises strategies in a two-way feedback process with the market and so delays shifting resources from growth to cost cutting until such time as the market can appreciate the business wisdom of the shift. Id. at 1027, 1042-43. The delay is suboptimal, and the later change of direction is abrupt. The more the manager cares about the stock price, the more dramatic the oscillation. Id. at 1035.

${ }^{151}$ See Lucian Arye Bebchuk \& Lars A. Stole, Do Short-Term Objectives Lead to Underor Overinvestment in Long-Term Projects?, 48 J. FIN. 719, 720 (1993) (demonstrating that, where information about long-term investment is available to investors, overinvestment may result because long-term investment may be seen as a signal of a positive long-term outlook). Carrying this out a step, similarly situated managers with reputational concerns may "herd" into a subset of favored but suboptimal investments. See Stein, supra note 137, at 132-33; see also Jill E. Fisch, Measuring Efficiency in Corporate Law: The Role of Shareholder Primacy, 31 J. CORP. L. 637, 672 (2006) (describing the connection between overvalued stock and value-destroying decisionmaking).

${ }^{152}$ See Alfred Rappaport, The Economics of Short-Term Price Obsession, FIN. ANALYSTS J., May-June 2005, at 65, 65 (discussing investors' and managers' "mutually reinforcing obsession with short-term performance"). In addition, those who actively manage their portfolios tend to hold stocks for short periods. Id. at 66-68.

${ }^{153}$ Managers have been shown to be more sensitive to accounting earnings than to cash flows. See John R. Graham et al., The Economic Implications of Corporate Financial Reporting, 40 J. ACCT. \& ECON. 3, 6 (2005) ("[A]ccounting earnings matter more to managers than cash flows for financial reporting purposes ....").

${ }^{154}$ Investment activity can negatively impact near-term earnings because the amount funded must be expensed, as is the case with R\&D costs. Prioritizing earnings can also mean delaying other expenses, such as maintenance or advertising, even though management believes that present action enhances long-term firm value. Alternatively, managers making a capital investment decision can face a choice between one project with higher later cash flows and higher present value (but lower near-term earnings) and a project with higher earlier cash flows and lower present value (but higher near-term earnings). For one study which examines such choices, see Sanjeev Bhojraj \& Robert Libby, Capital Market Pressure, Disclosure Frequency-Induced Earmings/Cash Flow Conflict, and Managerial Myopia, 80 ACCT. REV. 1, 2 (2005). Maximizing long-term value signals the first investment, while maximizing near-term EPS signals the second.

Numerous scholars have tested this empirically. See Brian J. Bushee, The Influence of Institutional Investors on Myopic RE'D Investment Behavior, 73 ACCT. REV. 305, 306-07, 
a given CEO's pay is to the stock price, the higher the level of earnings management at the firm. ${ }^{155}$

In summary, maximizing the corporation's fundamental value and maximizing its stock price can amount to distinct objectives in the presence of information asymmetries. Directors can attach a value to the corporation that is not only different from that reflected in the market price but better informed. When directors opt to maximize the stock's present appeal they may in the end sacrifice long-term shareholder value. Consequently, managing to an underinformed market price holds out intrinsic risks for business policy, particularly investment policy.

\section{Idiosyncratic Volatility}

We note that a recent line of empirical studies is thought to cut against the foregoing results. These studies assert that the shareholders' information asymmetry problem diminished substantially as the securities markets developed and deepened over the last half century. They track the quantum of stock price variation explained by movements across the market as a whole, showing a substantial diminution over time, along with a concomitant increase in firm-specific, or "idio-

319-30 (1998) (showing that a responsive reduction of R\&D spending is likely in firms with low institutional holdings, but that in firms whose predominant owners are institutions with high portfolio turnover and momentum trading strategies ("transient" institutions), earnings management through $\mathrm{R} \& \mathrm{D}$ cuts is very likely); Brian J. Bushee, Do Institutional Investors Prefer Near-Term Earnings over Long-Run Value? 2-3 (Apr. 1999) (unpublished manuscript), available at http://ssrn.com/abstract=161739 (showing a weak institutional preference for near-term earnings amongst institutions as a whole, but a strong preference for near-term earnings within the transient subset, along with a concomitant tendency to hold companies whose stock is mispriced); see also Mei Cheng et al., Earnings Guidance and Managerial Myopia 1-4 (Nov. 2005) (unpublished manuscript), available at http://ssrn.com/abstract $=851545$ (using voluntary earnings guidance as a proxy for managing to the market). There is also survey evidence of this phenomenon. See Graham et al., supra note 153, at 32-35, 35 fig.5 (surveying 401 chief financial officers and reporting that nearly eighty percent said that they would decrease discretionary spending on $\mathrm{R} \& \mathrm{D}$ or advertising to meet earnings targets, and just over fifty-five percent said that they would delay a new project despite a small sacrifice in value); see also John R. Graham et al, Value Destruction and Financial Reporting Decisions 9-10 (Sept. 6, 2006) (unpublished manuscript), available at http://ssrn.com/abstract=871215 (reporting that only fifty-nine percent of the same group of executives would approve a high net present value project if it entailed missing earnings by $\$ 0.10$ ).

${ }^{155}$ See Daniel Bergstresser \& Thomas Philippon, CEO Incentives and Earnings Management, 80 J. FIN. ECON. 511, 512-13 (2006) (finding evidence that CEOs whose compensation is more closely tied to share price "more aggressively use discretionary components of earnings to affect their firms' reported performance"). Otherwise, the underinvestment problem can be expected to be at its most acute when management has particularly strong incentives to please the market, as happens when new equity finance is needed or with takeover pressure. 
syncratic" volatility. ${ }^{156}$ The more particular implication, according to proponents of one reading of the data, is that market traders have somehow obtained enhanced access to private information. ${ }^{157}$ How that might have happened, however, is not explained. The evidence, moreover, is indirect, inferential, and in dispute. ${ }^{158}$ The literature holds out at least four competing explanations of the data, ${ }^{159}$ resulting in a state of explanatory gridlock.

${ }^{156}$ According to one study, it was thirty times higher in 1997 than in 1962. See John Y. Campbell et al., Have Individual Stocks Become More Volatile? An Empirical Exploration of Idiosyncratic Risk, 56 J. FIN. 1, 20, 24 fig.5 (2001) (showing that variance for a typical firm was thirty times higher in 1997 than in 1962, while the equally weighted average $R^{2}$ statistic of a market model declined from 0.26 to 0.08 across the same period). The studies follow from Richard Roll, $\mathrm{R}^{2}, 43 \mathrm{~J}$. FIN. 541 (1988), which showed that market models could explain a lesser quantum of daily volatility than previously had been assumed. Id. at 542-43.

${ }^{157}$ If that is the case, then the information asymmetry problem has been ameliorated to some extent. Carrying this point a step further, some proponents posit that good managers look to the stock price to get good instructions for business policy, claiming not only well-informed but accurate stock prices. See Artyom Durnev et al., Does Greater Firm-Specific Return Variation Mean More or Less Informed Stock Pricing?, $41 \mathrm{~J}$. ACCT. RES. 797, 798-99 (2003) (evidencing an empirical connection between low $R^{2}$ and the informativeness of the stock price, and, by implication, its accuracy); Art Durnev et al., Value-Enhancing Capital Budgeting and Firm-Specific Stock Return Variation, 59 J. FIN. 65, 89 (2004) [hereinafter Durnev et al., Value-Enhancing Capital Budgeting] (finding better-quality investment decisionmaking at low $R^{2}$ firms, thus suggesting that informative stock prices facilitate efficient investment); see also Qi Chen et al., Price Informativeness and Investment Sensitivity to Stock Price, 20 REV. FIN. STUD. 619, 620-23 (2007) (showing a further correlation between stock price variation and the sensitivity of the firm's level of investment to its stock price).

${ }^{158}$ Even the studies' authors point to their weaknesses: the evidence as to price informativeness is only indirect, the implications are a matter of "theoretical conjecture," and other factors could be involved. Durnev et al., Value-Enhancing Capital Budgeting, supra note 157, at 69; see also Chen et al., supra note 157, at 625 ("Admittedly, it is ... possible that our measures are correlated with other factors .... We believe that our extensive robustness tests mitigate this concern to a large extent. But, it remains possible that something else is behind our results."). Idiosyncratic volatility, then, does not prove that the price has become better informed and more accurate-it only suggests such.

${ }^{159}$ The stepped-up volatility could also reflect (1) trading "frenzy unrelated to concrete information," Roll, supra note 156, at 566; (2) increased cash flow volatility within the companies, Campbell et al., supra note 156 , at $37-40$; (3) speedier information dissemination over time, $i d$. at 39; or (4) increased volatility in investor discount rates, id. at 39-40. Empirical evidence has been marshaled to support each of the four alternatives. See Steven X. Wei \& Chu Zhang, Why Did Individual Stocks Become More Volatile?, $79 \mathrm{~J}$. BuS. 259, 261-62 (2006) (showing that a decline in return on equity and, hence, greater uncertainty explain the increase in volatility, and attributing two-thirds of the increased volatility to newly listed firms); Yexiao Xu \& Burton G. Malkiel, Investigating the Behavior of Idiosyncratic Volatility, $76 \mathrm{~J}$. Bus. 613, 614 (2003) (finding from cross-sectional regressions that idiosyncratic volatility is related to trading volume, institutional ownership, and a growth posture); Michael W. Brandt et al., The Idiosyncratic Volatility Puzzle: Time Trend or Speculatixe Episodes? 13-14 (Univ. of Tex. McCombs Sch. 
Gridlock or not, evidence that the market has become better informed does not by itself imply that information asymmetries have actually decreased. Both public and nonpublic information may have improved, leaving the gap between the two unchanged. Consequently, there is simply no evidence to prove the assertion that the gap between private and public information available to the market has narrowed materially.

\section{Heterogeneous Expectations}

We now turn to the emerging literature of heterogeneous expectations. ${ }^{160}$ This line of financial economics has developed in an attempt to explain pricing bubbles, but it has broader implications for the debate over shareholder empowerment. Not long ago, many thought of bubbles as historical anomalies that happened before financial markets became as efficient as they are today. The historical parade of bubbles,

of Bus., Research Paper No. FIN-02-09, 2008), available at http://ssrn.com/abstract= 1141219 (conjecturing that idiosyncratic volatility is related to speculative euphoria); Jason Fink et al., IPO Vintage and the Rise of Idiosyncratic Risk 12-17 (Feb. 4, 2005) (unpublished manuscript), available at http://ssrn.com/abstract=661321 (showing a significant rise in idiosyncratic risk stemming from a drastic increase in the number of younger, riskier IPO firms in the market and demonstrating that after controlling for the proportion of young firms there is no time trend respecting idiosyncratic risk).

Other studies have begun to undermine some of the literature's basic assumptions. The conclusion that prices have become better informed is refuted by a study that ties the stepped-up volatility to increased opacity due to deteriorating accounting practices and increased dispersion of analysts' forecasts. See Shiv Rajgopal \& Mohan Venkatachalam, Financial Reporting Quality and Idiosyncratic Return Volatility over the Last Four Decades 1-6 (Sept. 2008) (unpublished manuscript), available at http://ssrn.com/abstract=650081. The consistent upward trend of volatility has also been challenged. See Brandt et al., supra, at 6-8, 37 fig. 2 (showing that the idiosyncratic volatility trend spiked during the period 2002-2004 and declined sharply thereafter through 2007, and identifying an earlier but shorter-lived trend toward increased volatility during the period 1926-1933); Paul Brockman \& Xuemin (Sterling) Yan, The Time-Series Behavior and Pricing of Idiosyncratic Volatility: Evidence From 1926 to 1962, at 12-14 (Sept. 2006) (unpublished manuscript), available at http://ssrn.com/ abstract=1117284 (documenting a downward trend in idiosyncratic volatility from 1926-1962).

${ }^{160}$ For the original model, see Edward M. Miller, Risk, Uncertainty, and Divergence of Opinion, 32 J. FIN. 1151, 1151 (1977). We do not claim to be the first to introduce this work in the legal literature. For two papers that have previously discussed its implications, see Lynn A. Stout, How Efficient Markets Undervalue Stocks: CAPM and ECMH Under Conditions of Uncertainty and Disagreement, 19 CARDozo L. REV. 475, 482-91 (1997), and Lynn A. Stout, The Mechanisms of Market Inefficiency: An Introduction to the New Finance, 28 J. CORP. L. 635, 639-50 (2003). For heterogeneous-expectations approaches to merger pricing, see Richard Booth, Discounts and Other Mysteries of Corporate Finance, 79 CAL. L. REv. 1053 (1991), and Lynn A. Stout, Are Takeover Premiums Really Premiums? Market Price, Fair Value, and Corporate Law, 99 YALE L.J. 1235 (1990). 
and the busts that followed, include the Dutch tulip bubble of 16301637 , the South Sea bubble of $1710-1720$, the British railway boom from 1845-1846, the subsequent U.S. railway boom and bust in 1873, and the dramatic rise and crash of the U.S. stock market of the 1920s. But the bubble-to-bust experience of Japan between the 1980s and $1990 \mathrm{~s}^{161}$ and our own recent Internet bubble caused researchers to ask how such events can occur in a world where financial markets are thought to be generally efficient. As a consequence, explanations for bubbles are being integrated into broader financial models.

Heterogeneous expectations models integrate pricing bubbles into the conceptual framework of "high church" financial economics by assuming rational behavior by all investors. Investors are not only rational but assumed to have access to the same information, to employ standard valuation techniques, and to trade on fundamentals rather than on noise. The models depart from the asymmetric information literature in two critical respects. First, the models assume symmetric information not only among investors but between those inside and outside of the corporation. Second, the models drop the classical assumption of homogeneous investor expectations. Here, each investor is informed by the same set of information but develops her own estimate of fundamental value, ${ }^{162}$ an estimate that at any given moment may differ from the market price. Some investors form more optimistic expectations, while others are more pessimistic.

Models with heterogeneity of expectations have three primary implications for corporate governance: (1) the market price may no longer represent the views of the shareholders as a whole or even of a majority of the shareholders; (2) the market price may not represent the pro rata value of the corporation; and (3) mispricing is likely to affect investment behavior within the corporation, and this investment behavior may be detrimental to the corporation.

\section{The Models}

In the leading heterogeneous expectations models, investors overweigh their own estimates of firm value and undervalue the estimates of other investors. This generates optimists and pessimists and trading where the optimists buy stock from the pessimists. As infor-

${ }^{161}$ For a heterogeneous-expectations analysis of the Japanese bubble, see Robert $B$. Barsky, The Japanese Bubble: A 'Heterogeneous' Approach (Nat'l Bureau of Econ. Research, Working Paper No. 15052, 2009), available at http://www.nber.org/papers/w15052.

${ }_{162}$ This is frequently framed in terms of Tobin's marginal $Q$. 
mation flows, any particular investor may change from being optimistic to pessimistic or vice-versa. Such changes in position explain the high volume of trading that is typically observed during bubbles. ${ }^{163}$

Critically, the models depict stock prices as having two components: first, the fundamental value of the stock; and second, the present owner's option to sell her stock to an even more optimistic investor. ${ }^{164}$ The result is that, even in equilibrium, the stock price may exceed the valuation of the most optimistic investor. Even as this investor values the firm based on optimistic expectations as to future value, the speculative component makes this investor willing to pay an even higher price for the stock because of the option value of selling the stock to an even more optimistic investor. ${ }^{165}$ As a result, prices can differ systematically from fundamental value.

This prediction will sound radical to an observer steeped in ECMH and CAPM. ${ }^{166}$ But this literature in fact resonates quite well with "high church" financial economics. We note three important points of connection.

First, there is no claim that financial markets always operate in a state where heterogeneity of expectations causes prices to diverge from fundamental value expectations. Heterogeneity is likely to occur when there is a change in technology, when glamour companies emerge, or when companies running newer businesses with less established track records become an important part of the market. ${ }^{167}$

Second, the literature yields a picture of bubbles that can be read together with semi-strong ECMH. Bubbles have two defining empiri-

${ }^{163}$ See José A. Scheinkman \& Wei Xiong, Overconfidence and Speculative Bubbles, 111 J. POL. ECON. 1183, 1185 (2003) (noting that optimists and pessimists oscillate, changing their forecasts as information flows).

${ }^{164}$ For the original model of speculative behavior in a marketplace, see J. Michael Harrison \& David M. Kreps, Speculative Investor Behavior in a Stock Market with Heterogeneous Expectations, 92 Q.J. ECON. 323, 325-28 (1978).

${ }^{165}$ The more pronounced the differences of opinion among investors, the more salient the speculative element. See Patrick Bolton et al., Executive Compensation and Short-Termist Behaviour in Speculative Markets, 73 REV. ECON. STUD. 577, 578-80 (2006) (explaining the effects of differences of opinion on speculative behavior and thus fluctuating stock valuation).

${ }^{166}$ If CAPM's assumption of homogeneous expectation is relaxed, and some investors are well-informed while others are misinformed, the theory's prediction no longer holds. See Eugene F. Fama \& Kenneth R. French, Disagreement, Tastes, and Asset Prices, 83 J. FIN. ECON. 667, 669 (2007) (concluding that disagreement between dissimilarly informed investors moves pricing away from CAPM).

${ }^{167}$ See Stavros Panageas, The Neoclassical Theory of Investment in Speculative Markets 22-23 (Apr. 16, 2005) (unpublished manuscript), available at http://ssrn.com/ abstract $=720464$. 
cal markers: (1) a period of rapidly rising prices followed by a subsequent collapse; and (2) an unusually high volume of trading that cannot be explained by changes in fundamentals. Under the first marker, a bubble can only be identified after it has burst; rapidly rising stock prices do not constitute a bubble unless or until followed by a sharp decline or collapse. ${ }^{168}$ Ex post identification is not problematic for semi-strong efficiency, however, since there is no claim that a bubble can be identified ex ante. It follows that there is no implicit claim that a contrarian trading strategy can be developed that yields reliable profits from a bubble.

Third, the models do assume constraints on short selling that prevent arbitrageurs from eliminating upward bias in the stock price stemming from optimistic purchases. This assumption might have put them outside the "high church" tent twenty years ago. ${ }^{169}$ Today, however, the economic literature recognizes real-world limitations on the arbitrage correction function. ${ }^{170}$

${ }^{168}$ For example, then-Federal Reserve Chairman Alan Greenspan made his famous speech on "irrational exuberance" in December 1996. Alan Greenspan, Chairman, Fed. Reserve Bd., Remarks at the Annual Dinner and Francis Boyer Lecture of The American Enterprise Institute for Public Policy Research: The Challenge of Central Banking in a Democratic Society (Dec. 5, 1996), available at http://www.federalreserve.gov/ boarddocs/speeches/1996/19961205.htm. The stock market would come close to doubling over the next several years, with the bubble only bursting in late 2000 .

169 Traditional ECMH proponents never denied that many investors are uninformed and that their trading activities push the market price away from fundamental value. They instead posited that mispricing presents a risk-free arbitrage opportunity and that the arbitrage corrective will be complete, assuring that stocks have flat demand curves and insulating market prices from shocks stemming from shifts in supply and demand having no relation to fundamental value. See Myron S. Scholes, The Market for Securities: Substitution Versus Price Pressure and the Effects of Information on Share Prices, 45 J. BUS. 179, 179-82 (1972) (discussing various hypotheses regarding arbitrage opportunities resulting from market imperfections).

${ }^{170}$ Arbitrage in corporate stocks is risky. Individual stocks do not have perfect substitutes. Arbitrage hedges accordingly carry the risk that the two streams of returns do not cancel out. See Jeffrey Wurgler \& Ekaterina Zhuravskaya, Does Arbitrage Flatten Demand Curves for Stocks?, 75 J. BuS. 583, 585-86 (2002) (reporting the results of an empirical test of stocks that join the S\&P 500 and finding that no substitutes that would hedge away more than twenty-five percent of the daily return variance could be located). That risk must be compensated for by additional returns, which in turn cause a reduction in the number of attractive plays and reduce the volume of corrective trading. The smaller the number of corrective traders, the more risky their plays become. Moreover, even if an arbitrageur's fundamental-value analysis is flawless, a given play succeeds only when the rest of the market comes to share the analysis and moves the stock in the predicted direction. As the time to correction lengthens, so does the play's duration and risk. All of this calls for a substantial base of capital, which further depresses the number of potential players. 


\section{Implications for Business Policy and Corporate Governance}

The heterogeneous expectations models change a single classical assumption, homogeneous investor expectations, to drive a wedge between stock prices and fundamental value without resort to information asymmetries. Information asymmetry and heterogeneous expectations thus emerge as separate tracks for projecting the potential adverse effects of managing to the market.

\section{a. Implications for Shareholder Voting}

When shareholder proponents ask for shareholder voting on business-policy matters, they assume that the stock price offers a reliable proxy for fundamental value and so provides the shareholders with informational guidance. The information picture changes with heterogeneous expectations. Increases in the speculative component of the stock price provide little or no information on fundamental value enhancement, and a shareholder basing a vote on market price information could be greatly misled in supporting the company's management. Shareholder voting would reward those companies whose prices had an increased speculative component. As a consequence, managers interested in securing shareholder support for a business decision, such as executive compensation, would have an incentive to skew business policy in directions that excited speculative reactions in the market.

\footnotetext{
Regulatory and institutional constraints also dampen demand for shorting activity. See Ronald J. Gilson \& Reinier Kraakman, The Mechanisms of Market Efficiency Twenty Years Later: The Hindsight Bias, 28 J. CORP. L. 715, 725-31 (2003) (analyzing the difficulties of successful arbitrage in financial markets); see also Andrei Shleifer \& Robert W. Vishny, The Limits of Arbitrage, 52 J. FIN. 35, 38-43 (1997) (positing a model for agency constraints on arbitrage activity). But cf. Paul Asquith et al., Short Interest, Institutional Ownership, and Siock Returns, 78 J. FIN. ECON. 243, 245 (2005) (showing empirically that only a handful of stocks on the U.S. markets are short-sale constrained due to an unavailability of loanable shares). The average ratio of short interest to shares outstanding in February 2000 was only two percent. See Eli Ofek \& Matthew Richardson, DotCom Mania: The Rise and Fall of Internet Stock Prices, 58 J. FiN. 1113, 1118 (2003) (calculating average short interest to be approximately two percent of shares outstanding as compared to almost three percent for Internet stocks). This is an increase from a less than one-percent average during the period 1973-1979. See Stephen Figlewski, The Informational Effects of Restrictions on Shont Sales: Some Empirical Evidence, 16 J. FIN. \& QUANTITATIVE ANALYSIS 463, 471-72, 472 tbl.1 (1981) (listing the average short interest for stocks on the S\&P 500 from 1973-1979 as a percentage of total stock outstanding).
} 


\section{b. Implications for Business and Investment Strategy}

We now inquire into the distortionary potential of speculative prices for decisionmaking in corporate boardrooms, irrespective of shareholder voting. The models have two noteworthy features: first, their time frames cover only the period during which the bubble is still growing, thus excluding the effects of the bubble's bursting; second, they assume that the managers' duty is to maximize the stock price for the benefit of the current shareholders. Given these parameters, what is a fiduciary to do in a speculative market?

The directions are clear. In order to maximize the wealth of the corporation's current shareholders, management should first sell additional overpriced stock, thereby effectively lowering the company's cost of capital. ${ }^{171}$ Having sold the stock, managers should then approve increased capital expenditures. In a model from Stavros Panageas, this investment serves two "efficiency" purposes. "One is to increase the 'long run fundamentals' of the company according to the beliefs of the current owners," since the high stock price presumably indicates a high present value of growth opportunities. ${ }^{172}$ The other is to increase the speculative element, permitting the current owners to capture a larger resale value when they sell their stock. ${ }^{173}$

José Scheinkman and Wei Xiong reach a similar conclusion. ${ }^{174}$ Like Panageas, they see stock ownership as including an option to profit from other investors' overvaluations. ${ }^{175}$ Patrick Bolton joins Scheinkman and Xiong by pointing this out in an article on executive compensation. ${ }^{176}$ In this model, executives divide their time between increasing the fundamental value of the corporation and increasing the value of the speculative component in the stock price. ${ }^{177}$ In order

171 See Panageas, supra note 167, at 17 (noting that new investment does not increase long-run fundamental value but rather short-term resale price).

${ }^{172}$ Id. (emphasis added).

173 See id. (noting that the speculative element arises because of disagreement over the fundamental valuation of the corporation and captures the current owners' resale premium).

${ }^{174}$ Their focus is on management self-interest, and they find that managers may themselves profit by adopting strategies that boost the option or speculative component. See Scheinkman \& Xiong, supra note 163, at 1208 ("Firm managers may be able to profit by adopting strategies that boost the speculative component.").

${ }^{175} I d$. at 1184 .

${ }^{176}$ See Bolton et al., supra note 165 , at 578 ("The holder of a share then has not only a claim to future dividends but also an option to sell the stock to a more optimistic investor in the future.").

${ }^{177}$ See id. at 579 (explaining managers' short-term behavior in terms of the speculative component). 
to maximize the wealth of the current shareholders, the optimal compensation contract actually "overemphasize[s] short-term stock performance to induce managers to take actions that may increase the speculative component in stock prices." 178 Indeed, "[w] hen it is possible for future investors to overvalue the firm due to their optimism, it is in the interest of current shareholders to cater to such potential sentiment even at the expense of firm long-term fundamental value." ${ }^{179}$ In other words, it is in the interests of current shareholders for managers to have a short-termist view so as to maintain the speculative element in the stock price and give the current shareholders the possibility of selling to even more optimistic investors.

To get a better sense of the models' implications, hypothesize a stodgy technology company (hereafter "Stodgy") in the year 1998, at the heart of the high-tech bubble. Its managers want more momentum in the company's profile. They get an opportunity to buy an Internet operation that recently has gone public (hereafter "Cybershares"). Cybershares has never made a profit and is investing heavily in a number of innovative, web-related projects. Prospects for revenues, however, are shadowy. Cybershares' stock, initially sold to the public for $\$ 20$, now trades at $\$ 60$. Stodgy's managers negotiate the acquisition of Cybershares at a still higher premium price and submit the transaction to a special committee of its independent directors for approval. The independent directors take a dim view of the Internet's revenue-generating prospects and believe Cybershares to be overpriced. They do, however, expect the Internet price bubble to persist for at least the intermediate term, even as they perceive little fundamental value and predict an eventual bust. The shareholders are expected to favor the merger overwhelmingly. How should the independent directors of Stodgy vote?

Within the parameters of the heterogeneous expectations models, Stodgy's directors should vote in favor of the acquisition because the models define their fiduciary duties in terms of present stockholders, and the deal holds out the benefit of a speculative price enhancement for the company's stock that would generate present stock price maximization. The result holds for investment policy in general: even if the purchase of Cybershares reduces the fundamental value of Stodgy, the purchase improves the wealth of its current shareholders as long as the

\footnotetext{
${ }^{178} I d$ at 578 .

${ }^{179}$ Id. at 597.
} 
increase in the speculative component of the stock price outweighs the diminution of value in the fundamental component of the stock price. ${ }^{180}$

As already noted, the models focus only on pricing effects inside the bubble and do not factor in the likelihood of the bubble bursting. Let us relax this parameter in the merger case, allowing market participants to factor in the possibility of an eventual pricing correction. We now find Stodgy's directors facing a difficult choice. An investment made to increase the speculative element in the price but lacking in supporting fundamental value will benefit only those who sell before the bubble bursts, with longer-term holders and new investors left holding the deflated remains. ${ }^{181}$ The directors have no inside information but believe that the probability of the bubble bursting is higher than the probability assessment built into the market price. Unfortunately, the directors cannot convince the optimistic market that their own pessimistic expectations are correct. As long as the bubble persists, it will appear that they turned down a good deal in the eyes of their shareholders.

In the constrained context of the models, including their interpretation of corporate law, the directors should ignore their own business judgment. The result follows from the models' assumption of symmetric information. Given this, the directors' conclusion differs from the market's only with respect to subjective expectations about future outcomes; it does not follow from a position of informational superiority. There is no reason for the directors to assume that they have a better answer than the market; accordingly, they should give the current shareholders what they want.

\section{c. Implications for the Legal Model of the Corporation}

The prevailing legal model works differently because it instructs the directors to maximize the value of the "corporation" and not the stock price. Remember that in the bubble models, the stock price has both a fundamental value component and a speculative component. In our hypothetical, the speculative component is positive, which is why the merger can reduce the fundamental value yet still result in a higher stock price. The move to the legal model permits the Stodgy

${ }^{180}$ See Christopher Polk \& Paola Sapienza, The Stock Market and Corporate Investment: A Test of Catering Theory, 22 REV. FIN. STUD. 187, 187-90 (2009) (arguing that managers may rationally make investments that decrease long-term value in order to secure short-term gains).

${ }^{181}$ See id. (arguing that shorter-term investors will benefit from "catering" on the part of management). 
directors to take the fundamental value information into account in making their decision. This gives them a basis to vote against the merger in accord with their own business judgment.

Thus, the legal model, in holding out "corporate" value maximization, opens up a zone of discretion. Within it, Stodgy's directors may ignore the most optimistic shareholders who set the market price. Because the legal model imposes no duty to manage to the market when the directors' views about value differ from the market's view, the directors have no duty to approve the merger simply for the purpose of allowing those shareholders to sell their stock to more optimistic shareholders. More generally, the legal model permits the directors to consider a longer time horizon. In the hypothetical, longterm value is maximized accordingly.

Compare this with the Cybershares merger case under a hypothetical legal regime that models the directors as agents of the shareholders. This makes the merger much more difficult to resist, reducing the zone of directorial freedom of action to maximize long-term value. The market, which serves as a proxy for shareholder preferences, favors the deal. Under an agency model, the principal's preferences should control. The directors can still vote against the deal, citing fundamental value as a defense. But this defense no longer provides a complete answer under the law because it privileges the interests of one subset of principals (the pessimistic, long-term holders) over another (the optimistic, short-term holders). Here, where the assumption of a unitary shareholder has failed, the board must choose winners and losers within the group of principals. Arguably the market price, as objective money on the table, holds out the more principled decision rule. ${ }^{182}$

\section{d. Controlling Shareholders Compared}

In the above cases, directors face a dilemma in exercising their business judgment when it conflicts with the views of their sharehold-

${ }^{182}$ What of the impact of the shareholder franchise in the hypothetical? More facts would be needed. If the directors approve the merger, the subsequent shareholder vote will be in favor of the merger, but only so long as the bubble has not yet burst. Indeed, if the pessimistic shareholders are not locked in to their shareholdings, they will vote yes on the ground that the best course in the wake of board approval is to vote yes and sell. Only shareholders that, for whatever reason, cannot sell will vote no. If the board turns down the merger, no shareholder vote occurs. The shareholder franchise comes into play at the next annual meeting. If the bubble has not burst, the directors presumably will be punished. Indeed, even if the bubble has burst, shareholders may still be inclined toward punishment due to the missed opportunity to sell. 
ers as expressed in market prices. The heterogeneous expectations models contrast the case where there is a controlling shareholder, positing that controlling shareholders are likely to have a longer-term rather than a shorter-term outlook. ${ }^{189}$

The incentive shift toward long-term value maximization arises because the controller cannot or does not want to sell her shares, despite what she believes to be an inflated price. Constraints on the ability of controlling insiders to sell their stock have a number of sources, including IPO-related resale restrictions and negative tax consequences from capital gains realization. Perhaps more importantly, the sale of a large enough block causes the seller to lose her power as a controller. ${ }^{184}$

The locked-in controller will adopt a conservative investment policy consistent with the view that she will still be in control when the bubble bursts and the speculative component of the stock price goes to zero. In particular, she has no incentive to consider speculative mispricing when determining investment policy and no reason to accept negative-net-present-value investments that increase the value of the speculative component. On the other hand, the controlling shareholder can profitably adopt one prong of the noncontrollers' shorttermist strategy by causing the firm to sell additional shares into the overpriced market, thereby lowering the firm's cost of capital. Since the funds so raised need not be used for investment purposes, they can be put aside to repurchase the shares after the bubble has burst. ${ }^{185}$

\section{e. Implications for Management Compensation}

The perverse effects predicted by the models follow only to the extent that the managers have the option of selling into the market and do not hesitate to exercise it. As we have seen, when frictions prevent sales, the managers have no stake in managing to the speculative ele-

${ }^{183}$ See Panageas, supra note 167, at 21 ("Long-termism is just the extent of "entrenchment' of current 'major' shareholders in the firm.").

${ }^{184}$ The controller might also face insider trading restrictions under Rule 10b-5. 17 C.F.R. $\$ 240.10 \mathrm{~b}-5$ (2009).

${ }^{185}$ See Bolton et al., supra note 165 , at 595 (explaining that during speculative episodes, "the cost of capital is below the firm's long-run value"). The reduction in the cost of capital is consistent with the controller's belief that the expected return on the shares will be lower in the future.

Note that the controlling shareholder's time horizon lengthens to the extent that access to the trading markets is restricted. Given a partial constraint on liquidation of its position, the firm's investment policy would be partially open to short-term incentives-the controlling shareholder would determine investment using "some weighted average between share price and long term value." Panageas, supra note 167, at 22. 
ment in the stock price, and fundamental value information determines investment policy. ${ }^{186}$ It follows that equity-based compensation schemes that lack constraints on market sales exacerbate the suboptimal-investment problem. ${ }^{187}$ It also follows that compensation plans should seek to mimic as closely as possible the incentives of a controlling shareholder, the shareholder who will be deterred from selling into an overpriced market by the need to maintain the control position and its accompanying value. ${ }^{188}$

Now consider the impact of shareholder empowerment respecting the terms of compensation plans, given these choices. Presumably, shareholders who are asked the hypothetical question of whether they prefer directors to have long- or short-term incentives will most of the time express a preference for the long-term. This is because the longterm strategy maximizes the current stock price, at least in normal times when stocks trade without a speculative element. Given these conditions, shareholders can be expected to support compensation plans that constrain executive resales.

Contrast this with a company that has an upward-trending stock price subject to speculative influence. Here, shareholder voting preferences should shift to follow the stock price. After all, if the stock price is inflated, it is because the shareholders have bid it up in the hope that the trend will continue. Resale constraints are undesirable because they would discourage the managers from stoking the trend. From a policy perspective, then, shareholder empowerment can work at cross-purposes with the goal of reducing value-destroying short-termist behavior.

\section{Summary}

We have shown that information asymmetries can open a gulf between managing to maximize long-term fundamental value and managing to maximize the market price of the stock. We have also shown that speculative pricing under heterogeneous expectations can have the

${ }^{136}$ See Stavros Panageas, Speculation, Overpricing, and Investment-Theory and Empirical Evidence 17 (Nov. 15, 2003) (unpublished manuscript), available at http:// icf.som.yale.edu/pdf/seminar03-04/stravros.pdf (noting that if managers do not have frictionless access to markets, investment decisions are based on fundamental value).

${ }^{187}$ See Bolton et al., supra note 165, at 578-79 (explaining that an incentive compensation scheme keyed to short-term stock price enhancement at the sacrifice of long-term value can be optimal for a group of speculative shareholders).

${ }^{188}$ Short-termist incentives will not, however, be entirely absent. A controlling shareholder retains the incentive to sell additional shares into the overpriced market in order to reduce the cost of capital, an incentive shared with all managers of all companies. 
same result. In both cases, managing to the market leads to suboptimal results, with negative implications for shareholder empowerment.

When market prices are taken as governance inputs they accordingly need to be interpreted as a matter of business judgment. In our view, the prevailing legal model gets it right when it remits the judgment to the directors and their appointed managers. A recent empirical study confirms that directors do indeed use their discretion to the advantage of fundamental value. The study finds that managers look to the stock price when investing only in limited circumstances, and when so doing they successfully separate the fundamental value signal from the speculative signal. ${ }^{189}$ This positive report card underscores the case favoring the prevailing legal model's zone of directorial discretion.

\section{SHAREHOlders, MANAGERS, MARKETS, AND THE FINANCIAL CRISIS OF 2008}

In this Part we turn to the recent financial crisis and the claim that shareholder empowerment is the regulatory response that will restore trust in the system. ${ }^{190}$ Leading executives of financial firms-particularly those whose firms had to be saved by the federal government-have emerged as the poster children for the evildoers who caused the crisis. But did the problem arise because the managers were fiduciaries who violated the shareholders' trust, or because the managers were acting more like agents by managing to the market? Does manager culpability translate, as Arthur Levitt would have us believe, ${ }^{191}$ into a case for shareholder empowerment? Or did the shareholders take the lead on the road to crisis, rewarding the financial companies that took on the most leverage with higher stock prices, and penalizing those that did not?

In Section A we examine the financial crisis through the lens of the shareholders of the financial firms at its epicenter. In so doing, we highlight the place of managing to the market in the chain of causation. As we show, the evidence suggests that shareholders first fell in love, and then fell out of love, with the financial companies that were taking on the most risk and the most leverage. In Section B we turn to the question of the proper role of corporate governance in post-crisis

189 See Tor-Erik Bakke \& Toni M. Whited, Which Firms Follow the Market? An Analysis of Corporate Investment Decisions 3 (Nov. 18, 2006) (unpublished manuscript), available at http://ssrn.com/abstract=891570 (finding "that investment does respond to legitimate information in price movements, but only for firms that rely on outside equity financing and whose shares are not mispriced" (emphasis added)).

${ }^{190}$ See supra notes 1-15 and accompanying text.

191 See supra text accompanying note 8 . 
law reform, focusing on executive compensation and its central role both in fomenting the crisis and in fixing the system. Doing so removes shareholder empowerment from the reform picture.

\section{A. Financial Risk and Shareholder Inputs}

Figure 2 tracks the performance of the subset of bank stocks included in the S\&P 500 index against that of the entire S\&P 500 from January 2000 to March 2009. It shows that prior to the autumn of 2007, the banks handsomely outperformed the market as a whole, in rough correlation with its ups and downs. ${ }^{192}$ They then underwent a precipitous fall that presaged and outstripped that of the market as a whole, which began a year later. We note that Figure 2 understates the performance gaps. The relative weight of the financial sector within the S\&P 500 grew from $13.0 \%$ in 1999 to $22.3 \%$ in $2006,{ }^{199}$ only to retreat back to $13.6 \%$ in mid-2009. ${ }^{194}$ It follows that the S\&P 500, excluding finance, neither rose nor fell as much as the line indicates.

The stock market favored the banks between 2000 and 2007 because of rising earnings that resulted from wide spreads between expected returns on lending and the costs of increasing leverage in a stable economic environment. The problem, which became more and more apparent in 2007, was that the banks had been making high-yield loans into the residential-mortgage sector (including, but not limited to, subprime loans) that were much riskier than had been appreciated. Securitization ${ }^{195}$ had turned these risky loans into AAA paper on the assumption that the price of the real estate securing the loans would continue to rise. ${ }^{196}$ At the same time, the rise in real estate prices was built in part on increasing demand for housing fueled by ever-riskier real estate financing. ${ }^{197}$

192 The correlation of the two number series is 0.48 .

193 Bespoke Investment Group, Current and Historical Sector Weightings of the S\&P 500 (Apr. 24, 2008), http://bespokeinvest.typepad.com/bespoke/2008/04/ current-and-his.html.

${ }^{194}$ Select Sector SPDR Trust, Sector Returns by Year 1999-2009, at 2, http:// www.sectorspdr.com/shared/pdf/SPDR-Periodic_table-web.pdf (last visited Jan. 15, 2010).

See generally Steven L. Schwarcz, The Alchemy of Asset Securitization, 1 STAN. J.L. BUS. \& FIN. 133 (1994) (explaining how securitization works and how companies benefit from it).

${ }^{196}$ See, e.g., Floyd Norris, Market Shock: AAA Rating May Be Junk, N.Y. TIMES, July 20, 2007, at C1 (explaining the riskiness of AAA securities backed by subprime mortgages).

${ }_{197}$ See, e.g., Andrey Pavlov \& Susan Wachter, Subprime Lending and House Price Volatility 3 (Univ. of Pa. Inst. for Law \& Econ., Research Paper No. 08-33, 2009), available at 
Figure 2: S\&P 500/S\&.P 500 Banks, 2000-2009

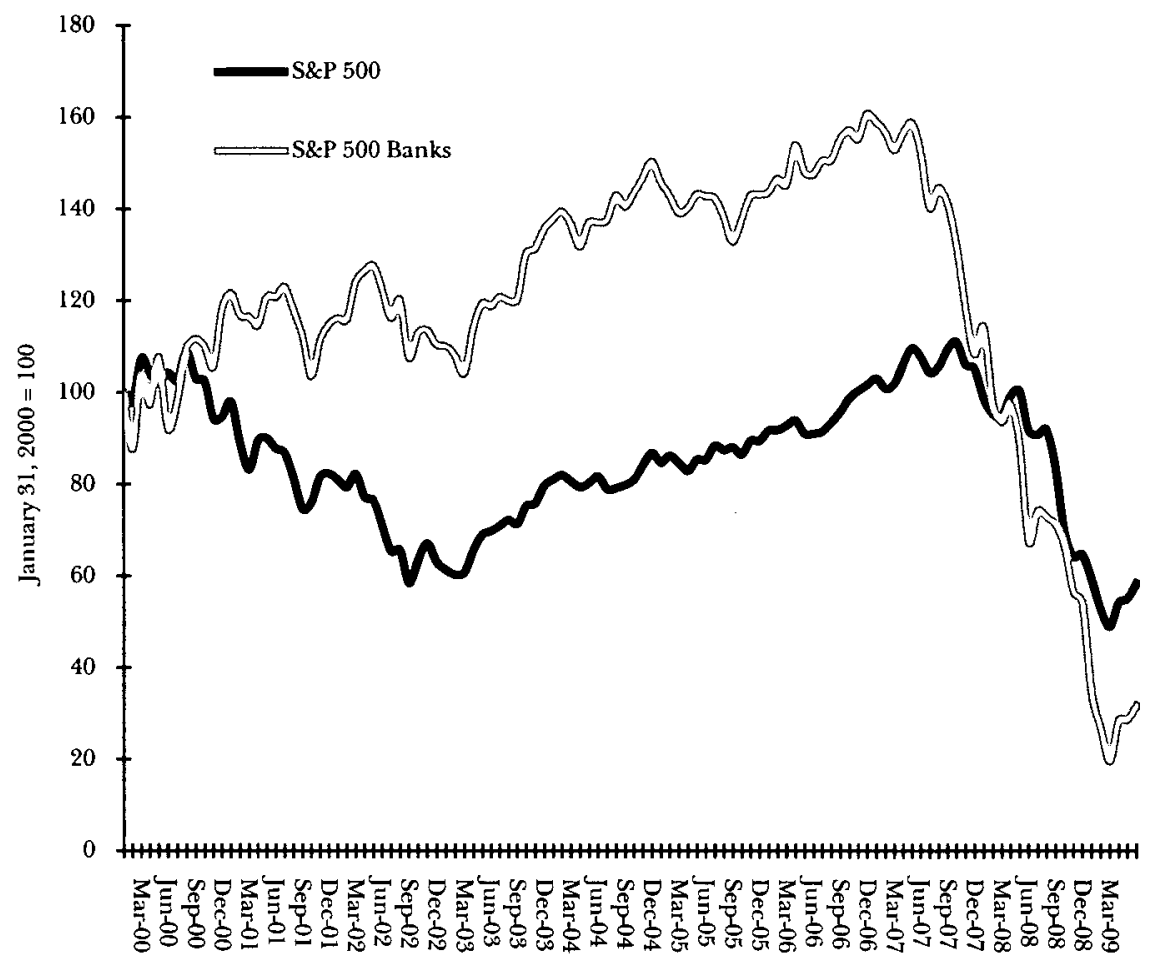

Was the crash of financial stocks the result of a system that gave managers too much power, or did it follow from managers catering to stockholders as they expressed their views through stock prices? Some evidence to answer the question can be found by breaking out individual financial stocks that were the poster children of the crisis, with each playing a different role. Figure 3 depicts the individual share prices of Countrywide Financial, JPMorgan Chase, and Bank of America against the S\&P 500 Bank index. Countrywide is now one of the clear villains in the story. But it also was the clear market favorite, at least until mid-2007. Countrywide expanded at a torrid pace after 2000 by making riskier loans, both in the subprime and prime sectors, and financing the expansion on a short-term basis in the repurchase

http://papers.ssrn.com/sol3/papers.cfm?abstract_id=1316891 (linking recent use of aggressive mortgage lending instruments and the underlying house price volatility). 
and commercial paper markets. ${ }^{198}$ Countrywide's line in Figure 3 stops in mid-2008 because portfolio losses forced it into a defensive merger with Bank of America.

It appears the stock market failed to appreciate the risks held out by the sector's higher fliers. In our view, this lack of appreciation can be traced partly to the information asymmetry problem described in Section III.B. As we noted there, markets can easily fail to measure the risk factors incorporated into discount rates. ${ }^{199}$ What was unusual here was the magnitude of the underestimation.

A full account of these events is beyond the scope of this Article, but a few useful points should be noted. Banks historically have been low-beta stocks. The banks, operating with less leverage than recently has been the case, made their profits on the spread between borrowing and lending rates. Since this spread does not generate enormous returns, the banks were steady earners with high dividends. Furthermore, by doing their best to match the duration of their assets with

198 In 2003, Countrywide was the star of its sector, having returned $23,000 \%$ on its equity between 1982 and 2003. See Shawn Tully, Meet the 23,000\% Stock, FORTUNE, Sept. 15, 2003, at 204 ("Most amazing of all is that Countrywide boasts the best stock market performance of any financial services company in the FORTUNE $500 \ldots$..."). Countrywide built itself into an industry leader with a strictly prime-lending operation, entering the subprime market only in 1999. Between 1999 and 2003, Countrywide got its growth in earnings and market share from an aggressive mortgage refinancing operation. That strategy depended on historically low interest rates. When rates climbed in 2003, it had to look elsewhere to continue its stellar performance. See Christine Richard \& David Feldheim, Asset-Backed Securities Gain Favor, WALL ST. J., May 25, 2004, at C5 (concluding that investors were moving money into asset-backed securities, creating a possible "bonanza" for consumer borrowing). Subprime lending was a part of the solution but only undertaken with a view to securitizing all mortgages originated. Prime lending remained a much greater part of the business. But here the company took a notably aggressive approach, originating adjustable-rate mortgages highly exposed to declines in real estate prices. See James R. Haggerty, Do Countrywide's Loans Stack Up?, WALL ST. J., July 25, 2006, at C3 (raising the possibility that Countrywide was less cautious than rivals in granting adjustable-rate mortgages). The right side of Countrywide's balance sheet also changed. Shareholders' equity, sixteen percent of total assets in 1999, declined to seven percent of total assets in 2006. Compare Countrywide Credit Indus., Inc., Annual Report (Form 10-K), at F-4 (Feb. 29, 2000), with Countrywide Fin. Corp., Annual Report (Form 10-K), at F-3 (Feb. 28, 2008). In 1999, the overwhelming portion of Countrywide's outside borrowing was medium term. By 2006, it was relying on short-term credit in the form of repurchase obligations and commercial paper. See Countrywide Fin. Corp., Annual Report (Form 10-K), at F-3 (Feb. 28, 2008) (reporting that repurchase obligations, while constituting $0 \%$ of liabilities in 1999 , were $23 \%$ in 2006 , while longer-term "notes payable" declined from $79 \%$ of liabilities in 1999 to $39 \%$ in 2006 ).

${ }^{199}$ See supra note 133 and accompanying text. 
their liabilities and maintaining large reserves of safe, liquid assets, they contained their risk, and hence their returns. ${ }^{200}$

\section{Figure 3: Sectoral Variations}

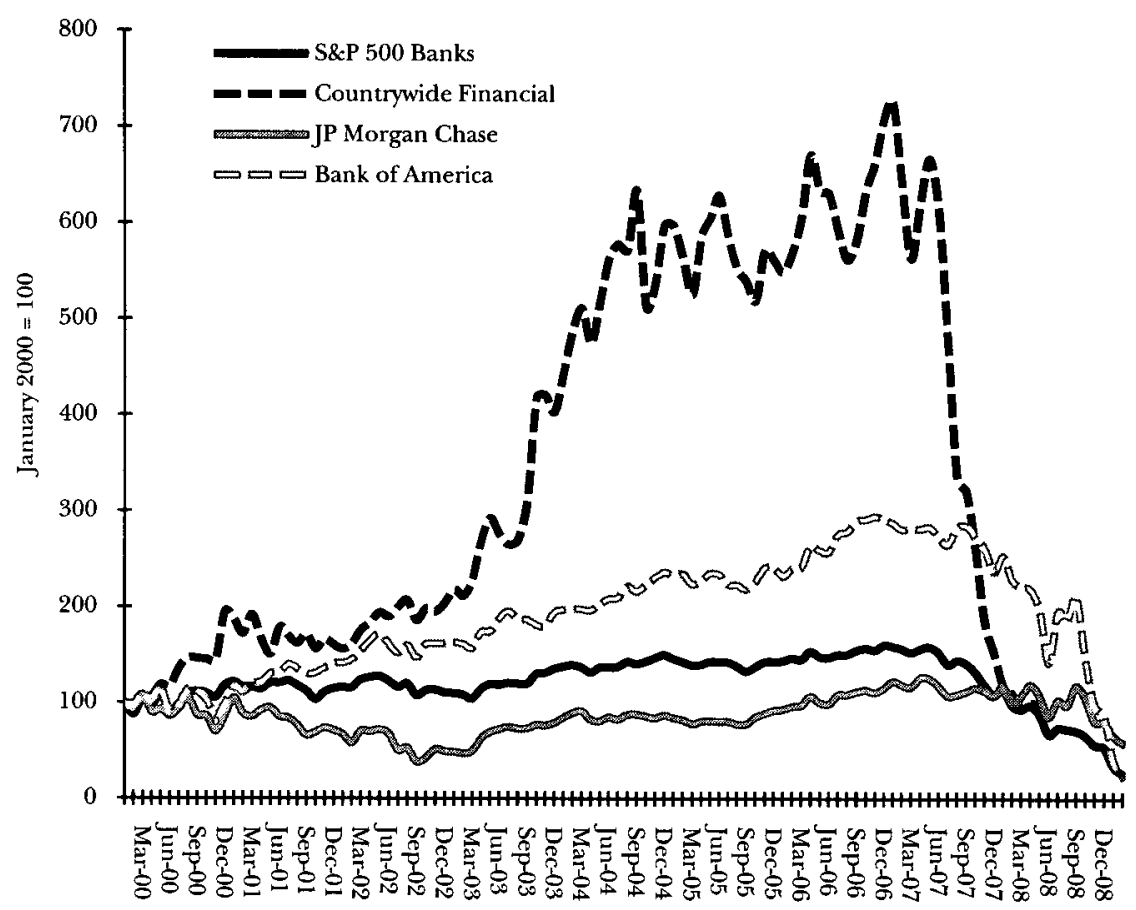

This all changed as some banks made riskier loans, became more involved in buying and selling securitized assets, and operated with more leverage. Such a change in business strategy meant a move to greater expected returns and greater risk. In the stable economic environment of 2003-2007, these banks generated much higher profits with little volatility. The stock market fell in love with this combination of unexpectedly high returns and apparently constant low risk. Higher stock prices resulted.

For a management dedicated to maximizing shareholder value, the instruction manual was clear: get with the program by generating more risky loans and doing so with more leverage. Any bank whose managers failed to implement the new math of high returns and low beta got

${ }^{200}$ For a description of the process by which banks went from regulatory constraint to high-risk investing, see RICHARD A. POSNER, A FAILURE OF CAPITALISM: THE CRISIS OF '08 AND THE DESCENT INTO DEPRESSION 41-74 (2009). 
stuck with a low stock price. ${ }^{201}$ For an example, look at JPMorgan Chase in Figure 3. It suffered from loan and other investment losses from 2001 to 2004, and then, as the housing bubble expanded, recovered while adhering to strict risk-management policies. ${ }^{202}$ Consequently, its stock lagged behind the bank index until the crisis began to unfold and then overtook the index. Unsurprisingly, its managers labored under considerable pressure to follow the strategies of competing banks. ${ }^{203}$ JPMorgan Chase had merged with a view to dominating the securitization business. ${ }^{204}$ In 2005, the new bank cranked up a production line for collateralized debt obligations based on subprime mortgages but never flicked the start switch because its managers could not find a way to make the risk/return numbers add up. ${ }^{205}$

As long as the economy was expanding, the riskier business strategies worked well. But when the economy slowed, the higher risk became observable. High returns went along with higher risk after all, and the realization caused stock prices to fall.

Now let us turn back the clock to 2005 and hypothesize a newly appointed CEO at a bank that has been pursuing the highgrowth/high-leverage strategy. The bank has been originating mortgages, both prime and subprime, whose soundness depends on continued rising real estate prices. Although it funnels most of its subprime originations into securitizations, some of these mortgages will be retained on its increasingly levered balance sheet. How would this CEO evaluate the policy? The stock market has been sending a strong signal that the shareholders love the new approach. If the CEO is shareholder sensitive, she will be inclined to view the new strategy as terrific. If that is the case, then the bank's fortunes are set. However, suppose the new CEO, who has had a long banking career, believes that the market is underestimating the risk of the high-growth/highreturn strategy built around originating risky mortgages on a more levered balance sheet. The new CEO accordingly decides against taking

${ }^{201}$ For a smaller bank, that meant becoming an attractive merger target as the industry concentrated.

${ }^{202}$ See Kate Kelly, STREet Fighters: THE LAST 72 Hours OF BEAR STEARnS, THE TOUGHEST FIRM ON WALL STREET 194-96 (2009) (describing JPMorgan Chase CEO Jamie Dimon's approach as "steer[ing] the bank away from risky holdings"); GILLIAN TETT, FOOL'S GOLD: HOW THE BOLD DREAM OF A SMALL TRIBE AT J.P. MORGAN WAS CORRUPTED BY WALl STREeT GREEd AND UNLEASHEd A CATASTROPHE 110-142 (2009) ("Dimon believed strongly that risks must be properly managed ....").

203 TETT, supra note 202, at 125-42.

${ }^{204} I d$. at 120.

${ }^{205}$ Id. at 121-28. 
on more leverage and orders the managers to stop originating both subprime mortgages and "teaser rate" mortgages, prime mortgages requiring no down payment, and instead orders them to sell off as many as possible, even if that means realizing a loss and incurring other transaction costs.

Does the CEO's insightful move improve the stock price? The bank, which is forced to lower its earnings forecast substantially, can fully explain the development as a return to a lower-risk corporate strategy that it believes will pay off when the economy cools and the returns on the subprime mortgages turn negative. But the result of not giving the market what it wants can be painful. The new corporate policy is unlikely to be rewarded precisely because the stock market believes the existing high-leverage corporate strategy, duly ratified by a rising stock price, is the correct one. The hypothetical thus ends with the bank's stock price dropping substantially and the managers' stock options going underwater. The story, in short, tracks Part III's analysis of the problems confronting managers making investment decisions given speculative stock pricing under heterogeneous expectations.

Now return to the question asked in this Article's Introduction: would increased shareholder power have moderated the bank's risky business practices? We think the answer is no. While many of the CEOs of adversely affected financial institutions certainly must have agreed with the strategy, some might not have. It is not as if contrarian warnings were not on the table for all to see. The Economist began a series of warnings about real estate price bubbles in 2002. ${ }^{206}$ Managers at JPMorgan Chase saw warning signs in the subprime market in 2005 and so decided to stay out. ${ }^{207}$ Insiders at other banks must have posited similar conclusions. ${ }^{208}$ The question is whether increased shareholder empowerment would have emboldened these informed insiders into abandoning the strategy so popular on Wall Street or would have deterred them. The inference from the evidence lies clearly with the latter result. Citigroup's then-CEO, Charles Prince, spoke publicly of his own second thoughts in 2007 , late in the game. He chose to stick

${ }^{206}$ See To Burst or Not to Burst?, ECONOMIST, Sept. 7, 2002, at 68 (warning thenFederal Reserve Chairman Alan Greenspan to look out for a boom in share prices or house prices combined with a big increase in debt and overinvestment by firms). The warning became more focused by 2004. See Will It Be Different This Time?, ECONOMIST, Oct. 9, 2004, at 22 (predicting a crash of the U.K. housing market).

${ }^{207}$ TETT, supra note 202, at 122-24.

${ }^{208}$ Cf. Kara Scannell \& John R. Emshwiller, Countrywide Chiefs Charged with Fraud, WALL ST. J., June 5, 2009, at C1 (reporting SEC allegations that Countrywide executives saw warning signs and decided not to disclose that information to investors). 
with the program despite his second thoughts: "When the music stops, in terms of liquidity, things will be complicated. ... But as long as the music is playing, you've got to get up and dance. We're still dancing."209 His upwardly bouncing stock price surely set the motivating rhythms. ${ }^{210}$

The financial sector undertook high-risk/high-return strategies to enhance return on equity and raise stock prices. ${ }^{211}$ The executives who danced to the rhythm were compensated with stock options and restricted stock in addition to cash bonuses, and so had incentives roughly in alignment with those of their shareholders. ${ }^{212}$

At least in retrospect we know that the market underestimated the risk being taken and thus failed to provide an objective, critical reference point for monitoring purposes. To the contrary, stock prices confirmed the strategies until well past the point of no return. We think that Arthur Levitt got it exactly wrong. Shareholder power was a part of the problem and is not a part of the solution.

${ }^{209}$ Stephen Kotkin, A Bear Saw Around the Corner, N.Y. TimES, Jan. 4, 2009, at BU2 (reviewing and quoting from JAMES GRANT, MR. MARKET MISCALCULATES: THE BUBBLE YEARS AND BEYOND (2008)).

${ }^{210}$ A recent empirical study of executive compensation at financial companies compares those that did badly in the financial crisis (such as AIG, Bear Stearns, Citigroup, Countrywide, and Lehman) against those that did better (such as Berkshire Hathaway, Goldman Sachs, JPMorgan Chase, and Wells Fargo). Ing-Haw Cheng et al., Yesterday's Heroes: Compensation and Creative Risk-Taking 5-10, 22-26 (Oct. 2009) (unpublished manuscript), available at http://ssrn.com/abstract=1502762. The study finds (a) a statistically and economically significant connection between executive compensation and price-based measures of risk such as beta and stock return volatility; (b) that higher-paying firms were more likely to be in the tails of performance; and (c) a positive relation between residual compensation and subprime exposure. Id.; see also Rüdiger Fahlenbrach \& René M. Stulz, Bank CEO Incentives and the Credit Crisis 1, 12 (Eur. Corp. Governance Inst., Finance Working Paper No. 256/2009, 2009), available at http://ssrn.com/abstract=1439859 (reporting on an empirical study and showing "that there is no evidence that banks with a better alignment of CEOs' interests with those of their shareholders had higher stock returns during the crisis and some evidence that banks led by CEOs whose interests were better aligned with those of their shareholders had worse stock returns and a worse return on equity").

${ }^{211}$ See, e.g., William D. Cohan, Op-Ed., A Tsunami of Excuses, N.Y. TimEs, Mar. 12, 2009, at A23 (criticizing the testimony of financial executives to Congress who alleged that the financial crisis was unavoidable).

${ }^{212}$ The mix among stock options, restricted stock, and cash bonuses varied from company to company and from executive to executive within each company. For example, in 2006, Citibank disclosed a heavier weighting to cash bonuses, whereas Bank of America relied more on stock options. Compare Citigroup Inc., Definitive Proxy Statement (Schedule 14A), at 39-52 (Mar. 14, 2006), with Bank of Am. Corp., Definitive Proxy Statement (Schedule 14A), at 22-27 (Mar. 20, 2006). 


\section{B. The Changing Policy Context}

Financial collapse reorients policy agendas. Is the shareholder agenda helped or hurt by these developments? As noted above, a large clientele believes that market exuberance can be fixed by giving shareholders more say. We think the policy implications go in the opposite direction. What is needed is incentive compatibility for managers. Incentive compatibility and shareholder accountability, however, do not yield the same results.

We noted in Part III that the heterogeneous expectations models have an important implication for executive compensation plans. ${ }^{213}$ Equity-based incentive-alignment schemes need to filter out speculative market inputs. Long-term holding constraints, whether attached to restricted stock or stock options, are the means to the end. Professors Sanjai Bhagat and Roberta Romano recommend prohibiting resales of eighty to eighty-five percent of the equity granted until two to four years after the manager leaves the company, with such restrictions extending down the hierarchy to cover bonus plans for traders. ${ }^{214}$ The idea is to drive a wedge between the incentives of shareholders who are active in the market and those of managers. As we also noted in Part III, managers taking equity compensation under resale restrictions resemble blockholders more than the dispersed shareholders on whom reform proponents continue to focus.

The manager/shareholder wedge has a second significant effect. Market shareholders tend to diversify their holdings in order to minimize risk. ${ }^{215}$ Resale-constrained managers are underdiversified and presumptively carry more risk than portfolio investors. As they bear more risk they tend toward risk-averse investment strategies. Thus does the emerging consensus favoring strict resale constraints reverse long-held views respecting equity-based compensation, views shaped

${ }^{213}$ See supra text accompanying notes 186-88.

214 Sanjai Bhagat \& Roberta Romano, Reforming Executive Compensation: Focusing and Committing to the Long-Term 7, 12-13, 15-16 (Yale Law \& Econ., Research Paper No. 374, 2009), available at http://ssrn.com/abstract=1336978. The authors reason that a two-year minimum suffices to diffuse the incentive to manage earnings; by the end of four years the intermediate-term effects of the manager's contribution will have worked their way into the stock price. Id. at 7.

${ }^{215}$ See Frank H. EASTERBROOK \& DANIEL R. FISCHEL, THE ECONOMIC STRUCTURE OF CORPORATE IAW 30 (1991) ("[T] he vast majority of investments are held by people with diversified portfolios."); Kevin J. Murphy, Explaining Executive Compensation: Managerial Power Versus the Perceived Cost of Stock Options, 69 U. CHI. L. REV. 847, 858-59 (2002) (factoring free transferability and hedging into the opportunity cost of a stock option). 
during the 1980s. ${ }^{216}$ Stock options, which build in sensitivity to upside gain and insensitivity to downside loss, long have been deemed the compensation mode of choice because they counterbalance the risk aversion that accompanies the undiversified investments of human capital that executives make in their companies. Up until now, management stock resales have been viewed as a matter for contractual trade-off-because they make it possible for the executives to diversify their investment portfolios, they increase the value of the compensation plan to the recipient and so reduce costs of compensation to the corporate employer and its shareholders. $^{217}$

The times have changed. Even bank CEOs now acknowledge a need for boards to be scrupulous about compensation structures and incentives, toward the goal of "trust restoration." Bhagat and Romano, even as their proposal addresses the TARP compensation constraints for financial companies, nonetheless commend its resale restrictions for the boards of all publicly traded companies. ${ }^{219}$ Bebchuk and Spamann go farther still, at least with regard to TARP recipients, contending that any equity-based compensation scheme holds out a possibility of incentivizing excessive risk taking, due to the combination of high leverage and the equity's limited liability. ${ }^{220}$ They recommend basing incentive compensation on enterprise value rather than shareholder value-that is, rewards should be based on the value of a package of common stock, preferred stock, and bonds. ${ }^{221}$

${ }^{216}$ See generally Michael C. Jensen \& Kevin J. Murphy, Performance Pay and Top Management Incentives, 98 J. POL. ECON. 225, 261-62 (1990) (finding the relation between executive wealth and shareholder wealth to be small, partly because executive compensation structures were not highly sensitive to performance at the time).

${ }_{217}$ Critics of compensation plans have questioned this analysis in part, recommending resale restraints that balance the long-term time horizon with the executive's interest in liquidity and diversification. See BEBCHUK \& FRIED, supra note 130, at 174-76 (concluding that the efficient balance between restrictions on cashing out vested options and executives' interest in liquidity and diversification will vary from firm to firm). But cf. William W. Bratton, Supersize Pay, Incentive Compatibility, and the Volatile Shareholder Interest, 1 VA. L. \& BUS. REV. 55, 75 (2006) (recommending across-the-board resale constraints).

${ }^{218}$ See Green, supra note 5, at 3 ("Public trust depends on a responsible, measured attitude to compensation.").

${ }^{219}$ Bhagat \& Romano, supra note 214 , at 3-4.

${ }^{220}$ Lucian A. Bebchuk \& Holger Spamann, Regulating Bankers' Pay 3-4 (John M. Olin Ctr. for Law, Econ. and Bus., Discussion Paper No. 641, 2009), available at http://ssrn.com/abstract=1410072.

${ }^{221}$ Id. at 5-6; see also Viral V. Acharya et al., Corporate Governance in the Modern Financial Sector (recommending a focus on return on assets rather than return on equity), in RESTORING FINANCIAL STABILITY: How TO REPAIR A FAILED SYSTEM 185, 193-94 (Viral V. Acharya \& Matthew Richardson eds., 2009). 
These new views on executive compensation bespeak a seismic shift in thinking about shareholder-manager relations. Compensation is the margin on which business policymakers align the incentives. Formerly, the shareholders were seen as a unitary population for whose interest the stock price provided a robust proxy. Now we see that at certain critical times the shareholder interest can disaggregate, with some shareholders' interests diverging from near-term stock price maximization. In such times, maximizing the market price provides faulty instructions to managers, undermining the claims of shareholder proponents and supporting the need for managers to exercise their business judgment independently. Recent changes in notions about appropriate management incentives accordingly come as no surprise. The new model, which seeks to cast management in the mold of a long-term holder, may be more hypothetical than descriptive of actual shareholders at many companies.

\section{CONCLUSION}

This Article bases its case against shareholder empowerment on the modern financial economics of market pricing. It cites information asymmetry and new financial economic theories of speculative overpricing. We underscore the importance of the new economics by reference to bank stocks during the period 2000 to 2008-a reference that leads ineluctably to consideration of the implications of the financial crisis for corporate law's political economy. There, on the critical topic of executive compensation, we already see the shareholder interest, as manifested in the market price, retreating in the corporate governance system's rearview mirror.

Shareholder proponents will object, pointing out that banks are different. Their businesses are built on assets and liabilities with mismatched durations, necessitating a protective deposit-insurance regime. That in turn holds out moral hazard in the form of speculative investment, with prudential regulation following to square the circle. Producers of goods and services in other sectors do not hold out these special risks. As to them, the shareholder case remains intact, or so goes the argument.

We see it differently. Our case, albeit brought home at the extreme, is not thereby limited. We have shown that excessive reliance on market pricing poses problems for corporate governance. We certainly do not claim that shareholder inputs shaped by market prices are intrinsically unreliable. We do claim that mispricing is a salient possibility, more so in times of economic volatility. It follows that price signals 
need to be interpreted by an agent exercising sound business judgment, with the independent board of directors bearing that burden.

The shareholder case, in contrast, follows from a theory that merges agency-cost reduction, value maximization, and price signals into a unitary whole to yield a one-size-fits-all governance instruction. This Article breaks open this holistic theoretical construct. Once that is accomplished, the shareholder proponents have no riposte because they have never thought it necessary to confront the difficulties of balancing the benefits and detriments of market inputs and to restate their case in a realistic cost-benefit framework.

We have no idea what such a robust shareholder empowerment case might look like. Pending its articulation, we think any reform following from the shareholder agenda to be inopportune in the present context. The prevailing governance system has proven itself quite responsive to market inputs. Shareholder power has waxed over the past several decades as an endogenous market response to changes in the economic environment. The high residual agency costs of thirty years ago have been cured by cost-effective increases in market monitoring and director bonding. Money on the table has that effect.

Now, in the aftermath of the financial crisis of 2008, the question is whether the self-adjusting market mechanism proved overly responsive to shareholder pressure by staking executive fortunes on shortterm price effects. If the financial crisis teaches us anything, it is that managing to the market is the problem that needs to be addressed. That calls for recalibration of compensation mechanisms, not legislative change to increase shareholder power.

More generally, today's regulatory questions concern the constraint of business discretion in the wake of market failure, in particular, risk taking in pursuit of shareholder gain. Despite the shareholder proponents' recent reframing of their case in terms of trust, shareholder empowerment remains what it always has been-a strategy that looks to regulatory reform that enhances market control over the zone of discretion in which directors make business judgments.

Regulatory reform strategies henceforth could proceed in the opposite direction. The pure financial incentives that advantage shareholder inputs in expansive, deregulatory times register equivocally in the face of public demands for control of market risk taking. Debates on executive pay are beginning to bear out this point. Regulations that seriously address risk taking will bypass the shareholders to impose constraints on financial corporations directly, narrowing their zone of freedom of action. As between managers and shareholders, 
such initiatives cause power to flow the managers' way. With regulation comes the responsibility to comply, a burden that falls on directors and officers. The more extensive the forthcoming regulatory intervention, the more irrelevant the shareholder empowerment strategy will become. This strategy has, in our view, reached the outer limits of its effectiveness for the time being. 